\title{
Improvement of dyes removal from aqueous solution by Nanosized cobalt ferrite treated with humic acid during coprecipitation
}

\author{
Shaimaa M. Ibrahim ${ }^{1}$ - Abdelrahman A. Badawy² ${ }^{2} \cdot$ Hisham A. Essawy $^{3}$
}

Received: 1 August 2019 / Accepted: 9 October 2019 / Published online: 23 October 2019

(C) The Author(s) 2019

\begin{abstract}
Highly effective novel adsorbent $\left[\mathrm{CoFe}_{2} \mathrm{O}_{4}\right.$-humic acid(HA)] was synthesized by co-precipitation technique at pH 6 (H6) and $\mathrm{pH} 8$ (H8). XRD, $S_{\mathrm{BET}}$ and Zeta-potential measurements were used to study the physicochemical properties of the prepared nanoparticles. XRD results showed that the chemical treatment of $\mathrm{CoFe}_{2} \mathrm{O}_{4}$ by HA causes the appearance of carbon as new active sites for adsorption process. Batch adsorption tests were achieved to eliminate anionic remazole-red (RR-133) and cationic methylene blue (MB) dyes. The obtained data showed that $\mathrm{H} 6$ and $\mathrm{H} 8$ solids calcined at 300 and $500{ }^{\circ} \mathrm{C}$ have higher adsorption rate for removing of dye than unmodified cobalt iron mixed oxide. The removal reached $100 \%$ after a period of dye contact time $2 \mathrm{~min}$ and $30 \mathrm{~min}$ for RR and MB, respectively. The uptake of RR and MB was much affected by the $\mathrm{pH}$ of dye solution. The pseudo-second-order kinetic model was the most fitted well and the adsorption process followed the Langmuir isotherm model. The adsorption of dye on adsorbent was chemisorption process. The as-prepared adsorbents can be regenerated and reused four times for both dyes. The efficiency of the prepared nano-samples and durability as adsorbent were accomplished.
\end{abstract}

\section{Graphic abstract}

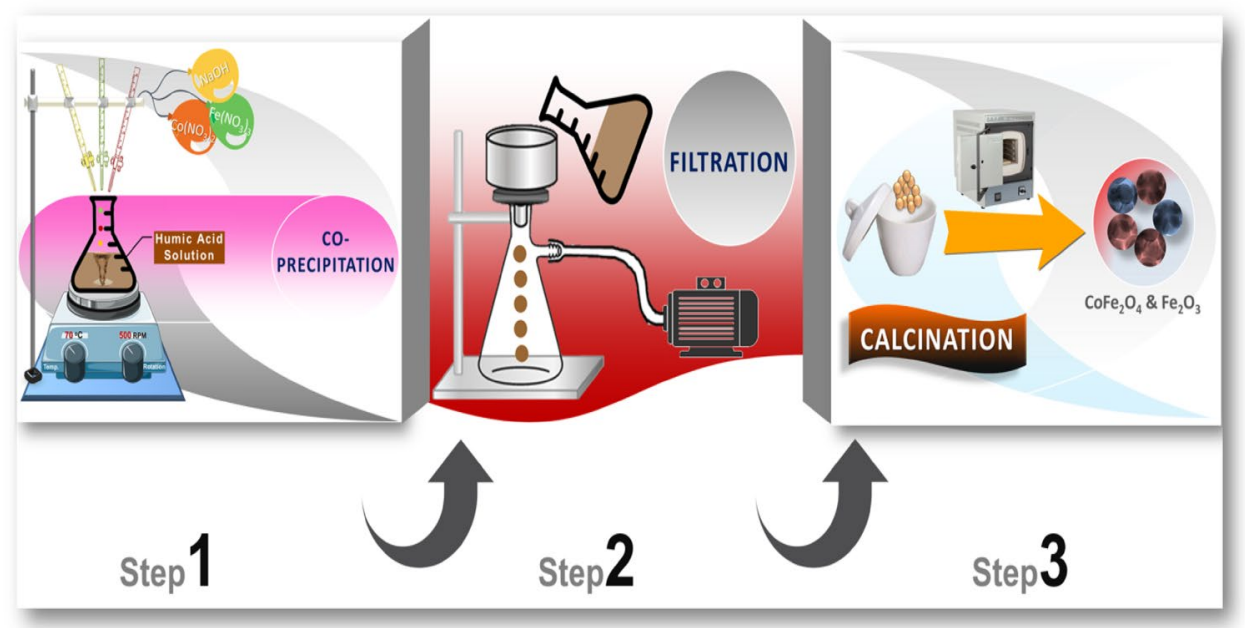

Keywords Remazole-red $\cdot$ Methylene blue $\cdot \mathrm{CoFe}_{2} \mathrm{O}_{4} \cdot$ Humic acid $\cdot$ Nanomaterials

Electronic supplementary material The online version of this article (https://doi.org/10.1007/s40097-019-00318-9) contains supplementary material, which is available to authorized users.

Abdelrahman A. Badawy

aabadawy107@yahoo.com

Extended author information available on the last page of the article 


\section{Introduction}

Water purification has a great interest by scientific researchers all over the world. Dyes, such as malachite green, remazole-red (RR), methyl orange, crystal violet and methylene blue (MB) are the most common effluents discharged directly to water resources. MB and RR are being used in several applications including textile and paper industries [1, 2]. MB has some medical uses for many therapeutic and diagnostic procedures [1-3]. However, MB and RR are a carcinogenic, non-degradable materials and causes serious environmental problems against aquatic animals, plants and human beings [4]. The existence of dyes in aqueous environments undesirably affects their esthetic nature [5-10]. Some side effects have been reported for MB and RR at high dosage such as eye burns, chest pain, fast breathing, confusion and profuse sweating [11]. Therefore, removal of MB from the wastewater is crucial. Adsorption is among current treatment technology for the removal of dyes from colored aqueous solutions [12].

Various technologies have been employed to remove organic dyes from industrial emissions such as coagulation-flocculation, biological, adsorption, membrane, ozonation, and advanced oxidation processes [12, 13]. Biological treatments are not sufficiently to adsorbed organic dyes and delight colored wastewaters due to the low biodegradability of organic dyes. Therefore, physicochemical processes have been used to degrade or remove organic dyes in aqueous solutions [13,14]. Adsorption using solid adsorbent is one of the physicochemical treatment approaches, and has been established to be efficient and economical [14]. In spite of, activated carbon was the most widely adsorbent employed but it has been limited due to its high capital and operative costs [11, 15-17]. Therefore, there is an increasing request to improve novel materials for appropriating organic dyes from aqueous media.

Nanomaterials resulting from definite mixed oxides are progressively employed as nano-sorbents in water-treatment technologies this due to nanomaterials have good sorption ability and excellent mechanical properties [18, 19]. Nano oxides entice pollutants significantly due to their advantages in recovering, non-toxic, recycling and high biocompatibility [20, 21]. Stabilization of nanoparticles is required as they are simply oxidized and agglomerated in aqueous solution [22]. The modification of oxides by integrated with organic constituents for example polyacrylic acid [23], chitosan [24], alginate [25] or humic acid [26] for pollutant removal were the object of several studies. Humic acid (HA) is a natural macromolecule derived from plant and animal decomposition in soil [27]. $\mathrm{HA}$ is a heterogeneous compound that has several groups such as carboxyl and hydroxyl groups. These groups of HA have good ability to bind metal ion in forming a complex of metal-HA [28]. HA interaction with oxides might be excellently inhibiting the collision of particle adhesion during the calcination process. The binding of HA with oxides has good resulting on the adsorbing properties of the oxides as HA bond yields a poly anionic organic coating so modifications the surface properties of oxides. Several investigations designated that HA has high attraction to $\mathrm{Fe}_{3} \mathrm{O}_{4}$ nanoparticles and raises the stability of nano dispersion by inhibiting agglomeration [29-31]. There are a lot of investigations shown the possibility of $\mathrm{Fe}_{3} \mathrm{O}_{4} /$ $\mathrm{HA}$ to be used as an appropriate substance for removing rhodamine B [32] and adsorbing methylene blue [33]. Our previous work [34] investigated the effect of Fulvic acid on mixed metal oxides derived from iron and cobalt via controlled coprecipitation. The results indicated that $\mathrm{CoFe}_{2} \mathrm{O}_{4}$ modified with Fulvic acid was an attractive candidate for removing textile (Remazole-Red (RR-133) dye from its aqueous solution and can be reused four times for dye removing, maintaining the same adsorption capacity.

This work is studying $\mathrm{CoFe}_{2} \mathrm{O}_{4}$ nanoparticles that has been prepared at $\mathrm{pH} 6$ and 8 in the existence/absence of HA extracted from peat soil. The materials of mixed oxides/ HA were established by mass ratios of mixed oxides and $H A=20: 1$. The physical and chemical characterization was scrutinized. The capability of the synthesized nanoparticles to degrade a carcinogenic pollutant textile dye as remazolered (RR-133) and/or methylene blue by controlling the removal condition was also investigated. The calculation of adsorption kinetics and isotherm of dye sorption was estimated on pure and mixed oxides/HA.

\section{Experimental}

\section{Chemical and preparation}

Ferric nitrate $\left[\mathrm{Fe}\left(\mathrm{NO}_{3}\right) \cdot 9 \mathrm{H}_{2} \mathrm{O}\right]$ and cobalt nitrate $\left[\mathrm{Co}\left(\mathrm{NO}_{3}\right)_{2} \cdot 6 \mathrm{H}_{2} \mathrm{O}\right]$ were Sigma-Aldrich products. All other chemicals were Prolabo Products and were employed as received. Cobalt ferrite $\left(\mathrm{CoFe}_{2} \mathrm{O}_{4}\right)$ was synthesized by wet chemical co-precipitation route $[34,35]$. Briefly, the nitrates of cobalt and iron were dissolved in distilled water at a designated molar ratio $(\mathrm{Fe} / \mathrm{Co}=1)$. $\mathrm{NaOH}$ solution $(1 \mathrm{M})$ was used as the precipitating agent. The metal nitrate solutions and $\mathrm{NaOH}$ were mixed in the presence/absence of humic acid by dropwise addition from three separate burettes into a combining reaction vessel containing $1 \mathrm{~L}$ of distilled water under mechanical stirring. The rate of addition was controlled to maintain a constant $\mathrm{pH}$ (6 or 8 ) during the co-precipitation process while the temperature was maintained at $70{ }^{\circ} \mathrm{C}$. $\mathrm{pH}$ meter (Model 331) was used for $\mathrm{pH}$ 
measurements. The precipitate was washed with plenty of distilled water until became free from $\mathrm{NO}_{3}{ }^{-}$and $\mathrm{Na}^{+}$ions. It was then filtered, dried at $100{ }^{\circ} \mathrm{C}$ overnight then calcined at 300,500 and $700{ }^{\circ} \mathrm{C}$ for $4 \mathrm{~h}$ to achieve lattice formation, as is shown in Scheme S1 (c.f. Supplementary Data Section, reported in S1).

\section{Techniques}

The phase crystallinity and crystallite size were determined by $\mathrm{X}$-ray diffraction (XRD) using $\mathrm{Cu}-\mathrm{K} \alpha$ radiations $\left(\lambda=0.15406 \mathrm{~nm}\right.$ ) in $2 \theta$ range from $20^{\circ}$ to $80^{\circ}$ (Bruker AXS D8 advance). The crystallite size of the phases present in the pure $\mathrm{CoFe}_{2} \mathrm{O}_{4}$ nanoparticles as well as the humic-modified samples was determined using the Scherrer equation (Eq. 1) [36]:

$d=K \lambda / \beta 1 / 2 \cos \theta$,

where $d$ is the mean crystalline diameter, $\lambda$ is the $\mathrm{X}$-ray wavelength, $K$ is the Scherrer constant (0.89), $\beta_{1 / 2}$ is the full width at half maximum (FWHM) of the main diffraction peaks of the crystalline phase present and $\theta$ is the diffraction angle. The area of main diffraction peak of the present phases was used as a quantity for their degree of crystallinity [37].

Quantachrome AS1WinTM-automated gas-sorption apparatus (USA) was employed to evaluate the surface characteristics of the samples by physical adsorption of nitrogen gas at $-198^{\circ} \mathrm{C}$. Before each sorption measurement, the samples were degassed at $200{ }^{\circ} \mathrm{C}$ for $2 \mathrm{~h}$. The adsorption on the samples was employed to determine the specific surface area $\left(S_{\mathrm{BET}}\right)$ by applying Brunauer-Emmett-Teller (BET) equation [38].

\section{Preparation of methylene blue and remazole-red (RR-133) solutions}

A stock solution of the dye was synthesized by dissolving a convinced weight of the dye in bi-distilled water. The desired concentrations for adsorption tests were prepared from the stock solution by dilutions. A curve was used to conclude the concentration of each experiment after UV-Vis spectroscopy measurements. This curve was used to convert absorbance data into concentrations for kinetic and equilibrium studies.

\section{Sorption studies and kinetic}

Batch equilibrium technique was employed for the adsorption of reactive $\mathrm{RR}$ and $\mathrm{MB}$ dyes solution from aqueous solution. $100 \mathrm{~mL}$ of dye solution of identified primary concentration was shaken with $50 \mathrm{mg}$ of the adsorbent and the mixtures were then kept at definite $\mathrm{pH}$ (at $25 \pm 0.1{ }^{\circ} \mathrm{C}$ ) for $3 \mathrm{~h}$ to reach equilibrium. Equilibrium isotherm studies were done with various primary concentrations varied between 10 and 100 ppm. Langmuir, Freundlich, Temkin and Dubinin-Radushkevich (D-R) isotherm models were employed to study the adsorption process.

The influence of dye concentration varying between 10 and $100 \mathrm{ppm}$ was examined also, at $25^{\circ} \mathrm{C}, 50 \mathrm{mg}$ adsorbent, contact time from zero to $3 \mathrm{~h}$ with stirring $150 \mathrm{rpm}$ and at $\mathrm{pH} 7$ using $\mathrm{H} 6$ and at $\mathrm{pH} 11$ using $\mathrm{H} 6$ and $\mathrm{H} 8$ for RR and $\mathrm{MB}$, respectively. Centrifuge of the solutions was at $7000 \mathrm{rpm}$ for $10 \mathrm{~min}$ and analyzed with UV-Vis spectrophotometer (Shimadzu UV/Vis1601 spectrophotometer, Japan) at appropriate wavelength of RR and MB dyes (i.e., 520 and $664 \mathrm{~nm}$, respectively).

The solution $\mathrm{pH}$ is important parameter that affects the adsorption performance of dye molecules. So, in our study the initial dye concentrations fixed at $50 \mathrm{ppm}$ and $\mathrm{pH}$ range 3-11 (using $0.1 \mathrm{M}$ of $\mathrm{HCl}$ and/or $\mathrm{NaOH}$ ) using $\mathrm{pH}$ meter OHAUSSTARTER 3000). The effects of solution $\mathrm{pH}$ on the removal percentage $(R \%)$ were studied in presence of $\mathrm{H} 8$.

The effect of time was studied to decide the time to equilibrium at $\mathrm{pH} 7$ or 3 with preliminary concentrations $50 \mathrm{ppm}$ at $25^{\circ} \mathrm{C}$. Kinetic experiments are the same to those of equilibrium tests but within time reached to $3 \mathrm{~h}$ or equilibrium. The pseudo-first-order and pseudo-second-order equations were designated by the following equations ( 2 and 3 , respectively) $[39,40]$ :

$\ln \left(q_{\mathrm{e}}-q_{t}\right)=\ln q_{\mathrm{e}}-k_{1} t$,

where $k_{1}\left(\mathrm{~min}^{-1}\right)$ is the rate constant of pseudo-first-order adsorption, $q_{t}$ is the amount of dye adsorbed at time $t(\mathrm{~min})$, and $q_{\mathrm{e}}$ is the amount adsorbed at equilibrium, both in $\mathrm{mg} / \mathrm{g}$.

$t / q_{t}=1 / k_{2} q_{\mathrm{e}}^{2}+t / q_{\mathrm{e}}$,

where $k_{2}(\mathrm{~g} /(\mathrm{mg} \mathrm{min})$ is the rate constant of pseudo-secondorder adsorption.

The parameters of pseudo-first-order $\left(q_{\mathrm{e}, \mathrm{cal}}\right.$ and $\left.k_{1}\right)$ and pseudo-second-order $\left(q_{\mathrm{e} \text {, cal }}\right.$ and $\left.k_{2}\right)$ values for Eqs. 2 and 3 can be considered from the slopes and intercepts of the linear plots of $\log \left(q_{\mathrm{e}}-q_{t}\right)$ against $t$ and $t / q_{t}$ versus $t$, respectively. Modified Weber and Morris equation was used to measure the intra-particle diffusion [41]:

$q_{t}=k_{\mathrm{dif}} t^{0.5}+c$,

where $q_{t}$ is the adsorption capacity at any time $t$ and $k_{\text {dif }}$ is the intra-particle diffusion rate constant $\left(\mathrm{mg} / \mathrm{g} \mathrm{min}{ }^{1 / 2}\right)$ and $C$ is the film thickness. $K_{\text {dif }}$ and $C$ values were designed from the slope and intercept of plots of $q_{t}$ versus $t_{0.5}$, respectively.

In addition, Elovich kinetic model was applied [42]:

$q_{t}=\beta \ln (\alpha \beta)+\beta \ln t$, 
where $\alpha$ (g/mg min) is the Elovich constant representing the initial adsorption rate and $\beta(\mathrm{mg} / \mathrm{g} \mathrm{min})$ is the desorption constant.

The removal percentage of dye $(R \%)$ was calculated by the following equation:

$\% R=\frac{C_{0}-C_{t}}{C_{0}} \times 100$,

where $C_{0}$ and $C_{t}$ are the concentration at time $(t=0)$ and time $t$, respectively.

The efficiency of the prepared nano-samples and durability as adsorbent were accomplished. $\mathrm{NaOH}$ or $\mathrm{HCl}$ solution $(0.1 \mathrm{M})$ was used to wash the adsorbent for $45 \mathrm{~min}$ according to the type of dye and then used for dye removal as formerly mentioned (Run 2). The same recipe was carried out for Run 3 and Run 4.

\section{Results and discussion}

\section{Characterization}

The diffractograms of mixed oxides synthesized in the existence and absence of humic acid are presented in Figs. 1, 2 and 3 and Table 1 .

Figure 1 shows, as mentioned before in our previous work [34], that the co-precipitation carry out at $\mathrm{pH} 6$ in the absence of any additives and heated at $300{ }^{\circ} \mathrm{C}(\mathrm{P} 6)$ carried out with a portion of $\mathrm{Fe}_{2} \mathrm{O}_{3}$ not intricate in the reaction $\left(2 \theta=33^{\circ}\right)$ even though the major phase was cobalt ferrite $\left(2 \theta=35^{\circ}\right)$. The existence of HA (H6 and H8) makes the process become more effective and no separate $\mathrm{Fe}_{2} \mathrm{O}_{3}$ was

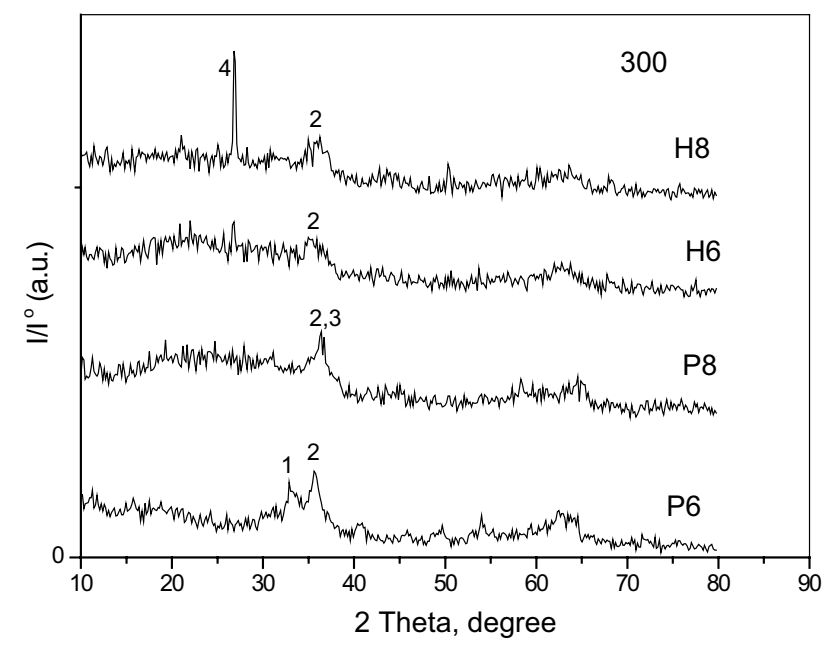

Fig. 1 XRD patterns of co-precipitations performed in the absence and existence of humic acid while calcined at $300{ }^{\circ} \mathrm{C} ; 1$ represents $\mathrm{Fe}_{2} \mathrm{O}_{3}, 2$ represents $\mathrm{CoFe}_{2} \mathrm{O}_{4}$ and 3 represents $\mathrm{Co}_{3} \mathrm{O}_{4}$; and 4 represents $\mathrm{C}$

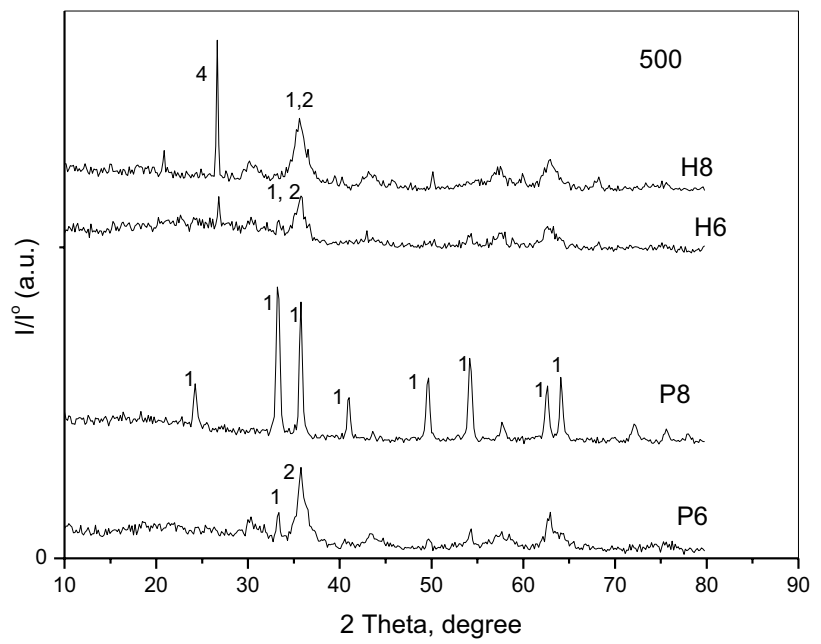

Fig. 2 XRD patterns of co-precipitations performed in the absence and existence of humic acid while calcined at $300{ }^{\circ} \mathrm{C}$; 1 represents $\mathrm{Fe}_{2} \mathrm{O}_{3}, 2$ represents $\mathrm{CoFe}_{2} \mathrm{O}_{4}$ and 3 represents $\mathrm{Co}_{3} \mathrm{O}_{4}$; and 4 represents $\mathrm{C}$

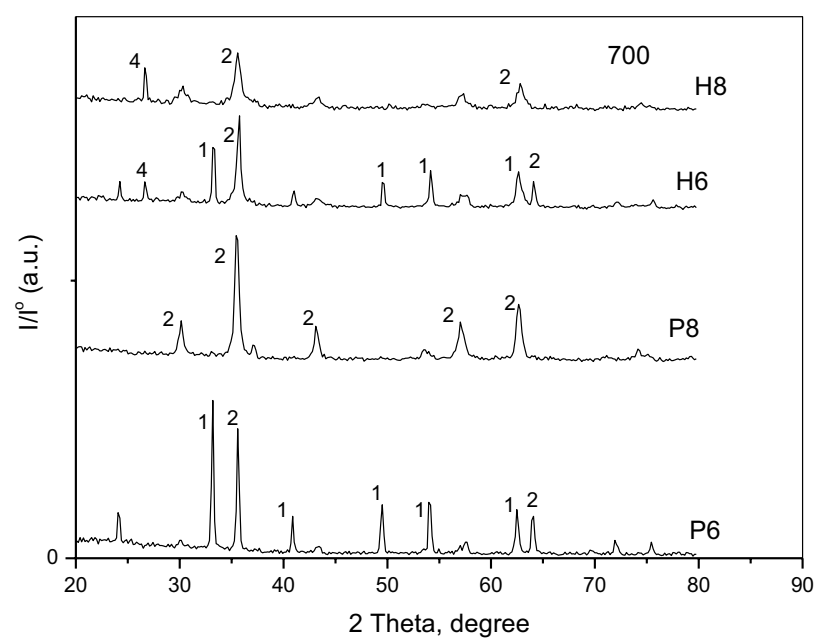

Fig. 3 XRD patterns of co-precipitations performed in the absence and existence of humic acid while calcined at $300{ }^{\circ} \mathrm{C}$; 1 represents $\mathrm{Fe}_{2} \mathrm{O}_{3}, 2$ represents $\mathrm{CoFe}_{2} \mathrm{O}_{4}$ and 3 represents $\mathrm{Co}_{3} \mathrm{O}_{4}$; and 4 represents $\mathrm{C}$

detected. The involvement of HA in the process (H6) led the formation of $\mathrm{CoFe}_{2} \mathrm{O}_{4}$ with lower crystallinity and the individual components (oxides) disappeared completely. Conversely, at $\mathrm{pH} 8, \mathrm{C}$ phase $\left(2 \theta=27^{\circ}\right)$ appeared beside the formation of $\mathrm{CoFe}_{2} \mathrm{O}_{4}$ in the presence of $\mathrm{HA}$ (H8). This can be described by the superior ability of HA to bind the individual oxides together at wide $\mathrm{pH}$ range.

The identical recipe was carried out in the same order with alteration that the calcination was $500^{\circ} \mathrm{C}$ (Fig. 2). It can be seen that in the absence of $\mathrm{HA}$ at $\mathrm{pH} 6(\mathrm{P} 6)$, the $\mathrm{CoFe}_{2} \mathrm{O}_{4}$ was formed together with $\mathrm{Fe}_{2} \mathrm{O}_{3}$ after the calcination while 
Table 1 Effect of humic acid and calcination temperature of co-precipitation derived from $\mathrm{CoFe}_{2} \mathrm{O}_{4}$ system on the peak area of the main diffraction peaks of $\mathrm{Co}_{3} \mathrm{O}_{4}, \mathrm{Fe}_{2} \mathrm{O}_{3}$ and $\mathrm{CoFe}_{2} \mathrm{O}_{4}$ as well as crystallite size of produced $\mathrm{CoFe}_{2} \mathrm{O}_{4}$
Scheme 1 A proposed mechanism of interactions between humic acid and ferric ion at $\mathrm{pH}$ 6 before calcination

\begin{tabular}{|c|c|c|c|c|c|}
\hline \multirow[t]{2}{*}{ Solids } & \multirow[t]{2}{*}{$\begin{array}{l}\text { Calcination tem- } \\
\text { perature }\left({ }^{\circ} \mathrm{C}\right)\end{array}$} & \multicolumn{3}{|c|}{$\begin{array}{l}\text { Peak area (a.u.) of diffraction lines peaks for the dif- } \\
\text { ferent phases }\end{array}$} & \multirow{2}{*}{$\begin{array}{l}\text { Crystallite size } \\
\text { of } \mathrm{CoFe}_{2} \mathrm{O}_{4} \\
(\mathrm{~nm})\end{array}$} \\
\hline & & $\mathrm{Fe}_{2} \mathrm{O}_{3}$ phase & C phase & $\mathrm{CoFe}_{2} \mathrm{O}_{4}$ phase & \\
\hline \multirow[t]{3}{*}{ P6 } & 300 & 14 & - & 16 & 7.4 \\
\hline & 500 & 14 & - & 34 & 11 \\
\hline & 700 & 130 & - & 106 & 73 \\
\hline \multirow[t]{3}{*}{ P8 } & 300 & - & 12 & 16 & 3 \\
\hline & 500 & 68 & - & - & - \\
\hline & 700 & - & - & 96 & 27 \\
\hline \multirow[t]{3}{*}{ H6 } & 300 & - & - & 12 & \\
\hline & 500 & 11 & 20 & 22 & 9.3 \\
\hline & 700 & 66 & 20 & 73 & 28 \\
\hline \multirow[t]{3}{*}{ H8 } & 300 & - & 33 & 11 & 3 \\
\hline & 500 & - & 67 & 30 & 8 \\
\hline & 700 & - & 34 & 41 & 14 \\
\hline
\end{tabular}

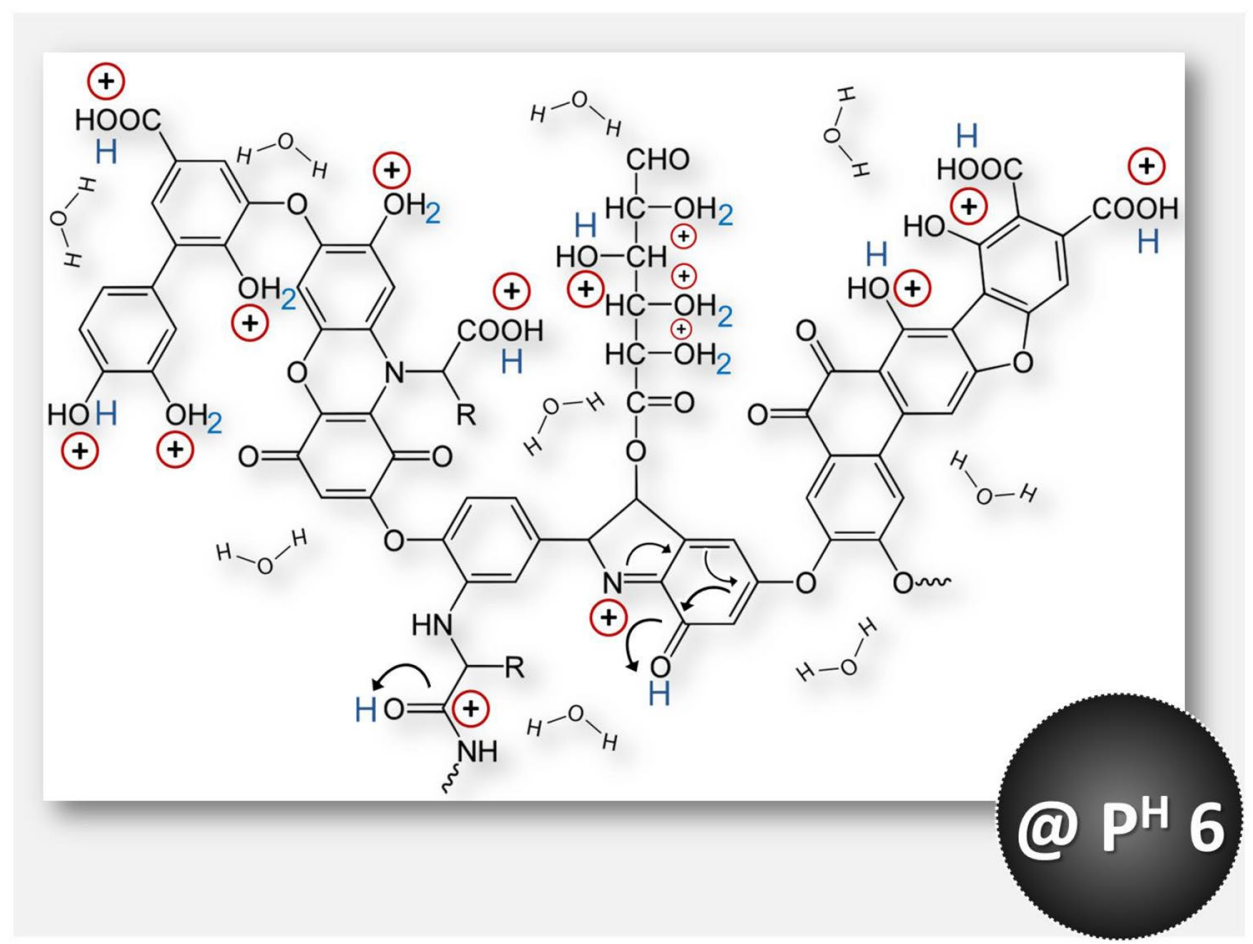

at pH 8 (P8) only $\mathrm{Fe}_{2} \mathrm{O}_{3}$ phase was formed with a welldefined crystalline structure. It was noticed that the insertion of $\mathrm{HA}$ at pH 6 and 8 ( $\mathrm{H} 6$ and $\mathrm{H} 8$ ), both $\mathrm{Fe}_{2} \mathrm{O}_{3}$ and $\mathrm{CoFe}_{2} \mathrm{O}_{4}$ were formed with distinct crystallinity. While, at $\mathrm{pH} 8$ (H8), the presence of HA led to the formation of $\mathrm{C}$ phase beside the two phases $\left(\mathrm{CoFe}_{2} \mathrm{O}_{4}\right.$ and $\left.\mathrm{Fe}_{2} \mathrm{O}_{3}\right)$.

For the samples calcined at $700{ }^{\circ} \mathrm{C}$ following the recipe prepared at $\mathrm{pH} 6$ without $\mathrm{HA}(\mathrm{P} 6)$, both $\mathrm{CoFe}_{2} \mathrm{O}_{4}$ and $\mathrm{Fe}_{2} \mathrm{O}_{3}$ were formed (Fig. 3). The presence of $\mathrm{HA}$ at $\mathrm{pH} 6$ (H6) led to formation of both $\mathrm{Fe}_{2} \mathrm{O}_{3}$ and $\mathrm{CoFe}_{2} \mathrm{O}_{4}$ with lower crystallinity beside the presence of $\mathrm{C}$ phase. The existence of HA at $\mathrm{pH} 8$ (H8) resulted in the formation of $\mathrm{CoFe}_{2} \mathrm{O}_{4}$ beside $\mathrm{C}$ phase. This can be illustrated as shown in Schemes 1 and 2 . Schemes 1 and 2 showed the interaction between HA and ferric ions at pH 6 and 8, respectively. Schemes 1 and 2 showed that HA affected by $\mathrm{pH}$ of solution and this influenced the interaction of it with ferric ions. This might reflect the role of $\mathrm{HA}$ in precipitation. The chemical treatment of $\mathrm{CoFe}_{2} \mathrm{O}_{4}$ by $\mathrm{HA}$ causes the appearance of carbon as new active sites for adsorption process thereby enhances the contents of active sites on the surface as will be discussed (c.f. "Effect of calcination temperature"). 
Scheme 2 A proposed mechanism of interactions between humic acid and ferric ion at $\mathrm{pH}$ 8 before calcination
Table 2 Surface characteristics and zero point charge of solids derived from different recipes after calcination at various temperatures

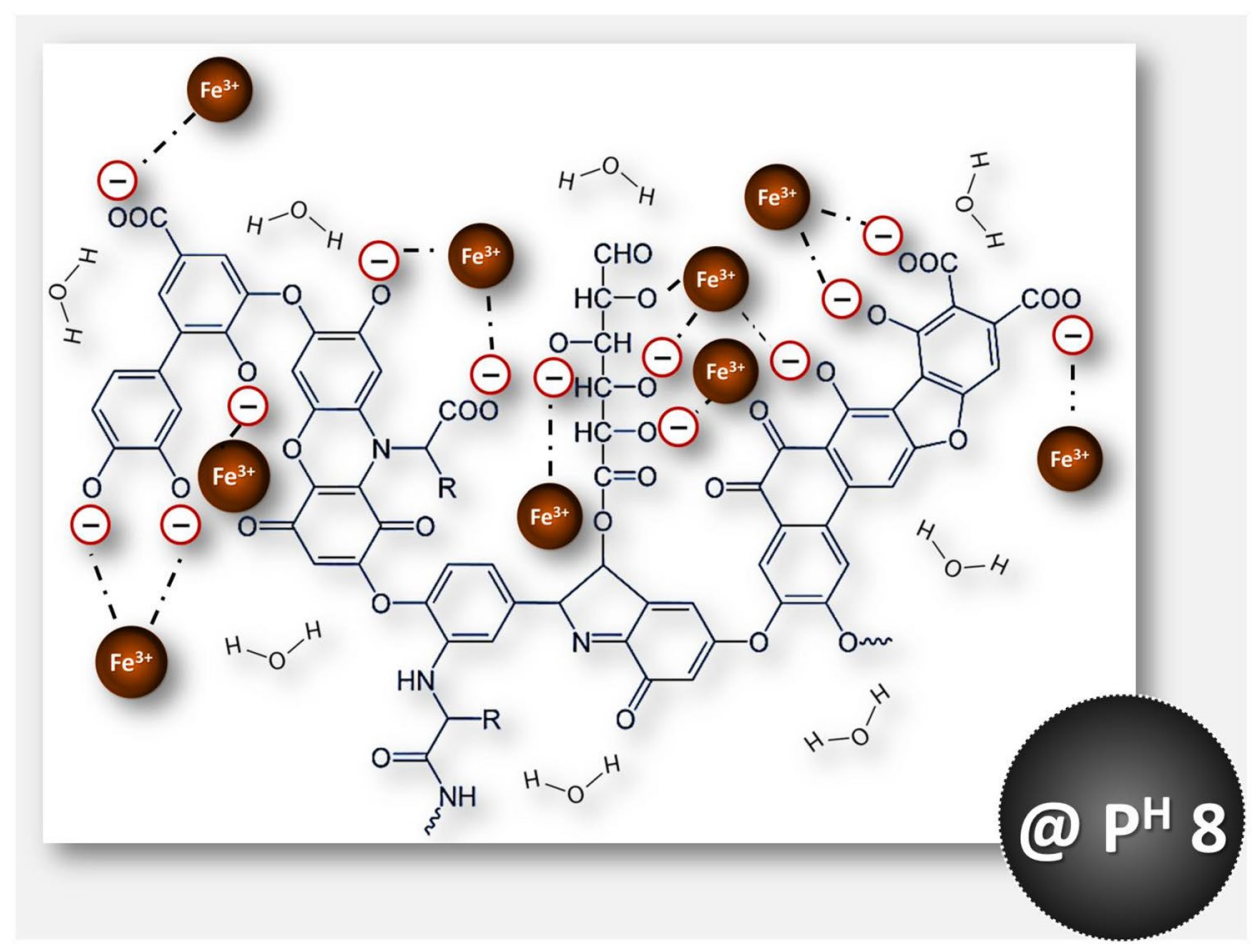

\begin{tabular}{llllll}
\hline Solids & $\begin{array}{l}\text { Calcination tem- } \\
\text { perature }\left({ }^{\circ} \mathrm{C}\right)\end{array}$ & $\begin{array}{l}S_{\mathrm{BET}} \\
\mathrm{m}^{2} / \mathrm{g}\end{array}$ & $\begin{array}{l}\text { Total pore volume } \\
V \mathrm{p}, \mathrm{cm}^{3} / \mathrm{g}\end{array}$ & $\begin{array}{l}\text { Mean pore radius } \\
r^{-}(\mathrm{nm})\end{array}$ & $\begin{array}{l}\text { Zero point } \\
\text { charge } \\
(\mathrm{pH} \mathrm{pzc})\end{array}$ \\
\hline P6 & 300 & 18 & 0 & 4.3 & 8.3 [ref. 34] \\
& 500 & 45 & 0.1 & 45 & 6.5 [ref. 34] \\
& 700 & 7.3 & 0.1 & 164 & - \\
$\mathrm{P} 8$ & 300 & 22 & 0 & 37 & 8.6 \\
& 500 & 34 & 0 & 5.2 & 6.7 [ref. 34] \\
& 700 & 21 & 0 & 29 & - \\
$\mathrm{H} 6$ & 300 & 35 & 0.1 & 28 & 6.6 \\
& 500 & 152 & 0.2 & 29 & 6.4 \\
& 700 & 16 & 0 & 247 & - \\
$\mathrm{H} 8$ & 300 & 21 & 0 & 37 & 6 \\
& 500 & 69 & 0 & 0.6 & - \\
\hline
\end{tabular}

Table 1 collects the features of the prepared $\mathrm{CoFe}_{2} \mathrm{O}_{4}$ in existence and absence of $\mathrm{HA}$ at various $\mathrm{pH}$ values $(6$ and 8). As a whole, it can be noticed that the crystallite size and degree of crystallinity are highly dependent on the $\mathrm{pH}$ of precipitation medium and calcination temperature.

BET analyses, the data collected in Table 2, clearly indicate that the HA modification increases the surface area and improves the morphology of the prepared samples. The observed decrease in $S_{\mathrm{BET}}$ values by increasing calcination temperature might be attributed to the increase in the crystallite size of $\mathrm{CoFe}_{2} \mathrm{O}_{4}$. It is obviously raising the calcination temperature of the as-prepared samples $\mathrm{H} 6$ and unmodified solids to $700{ }^{\circ} \mathrm{C}$ that has a negative effect on surface characteristics. But, this is different in the case $\mathrm{H} 8$ sample. The increase of $S_{\mathrm{BET}}$ of $\mathrm{H} 8$ might be due to pore widening.

\section{Dye adsorption tests}

\section{The influence of primary dye concentration}

Figure $4 \mathrm{a}-\mathrm{d}$ shows the influence of primary concentration of $\mathrm{RR}$ and MB dye (from 10 to $100 \mathrm{ppm}$ ) in the presence of $\mathrm{H} 6$ 
(a)

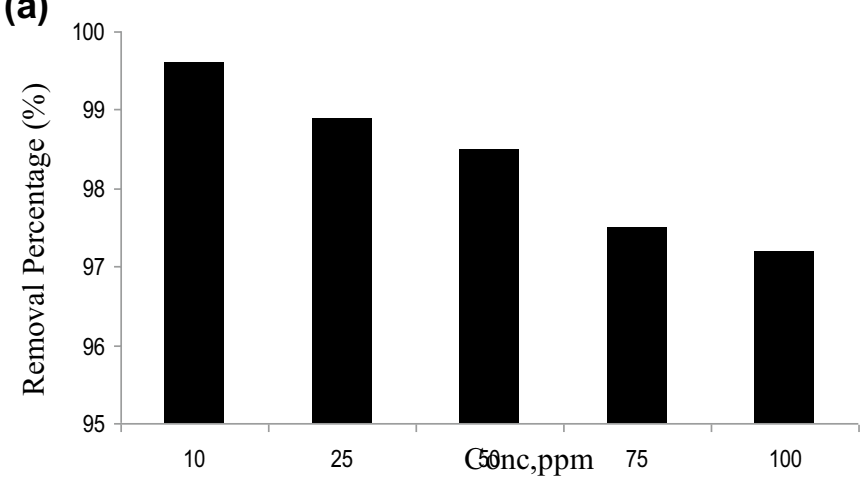

(c)

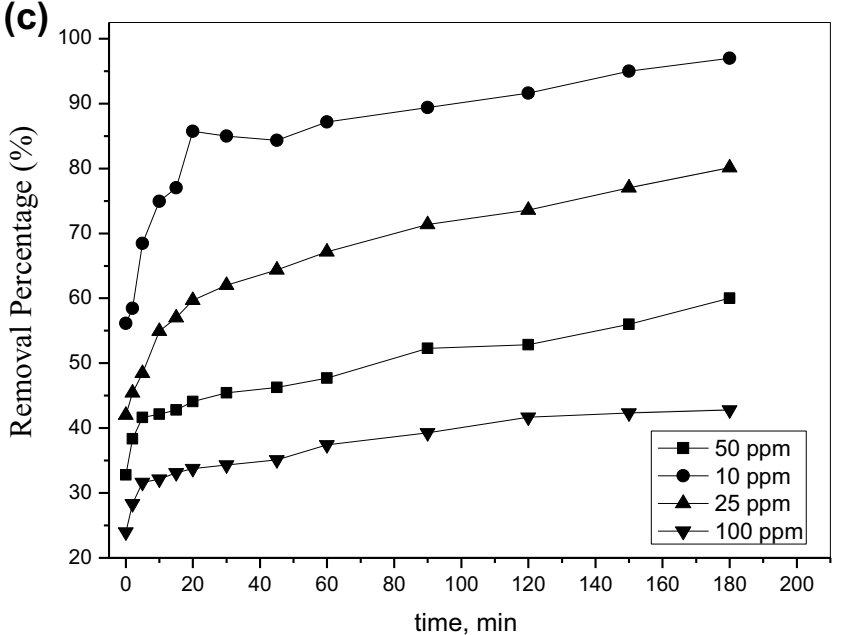

(b)

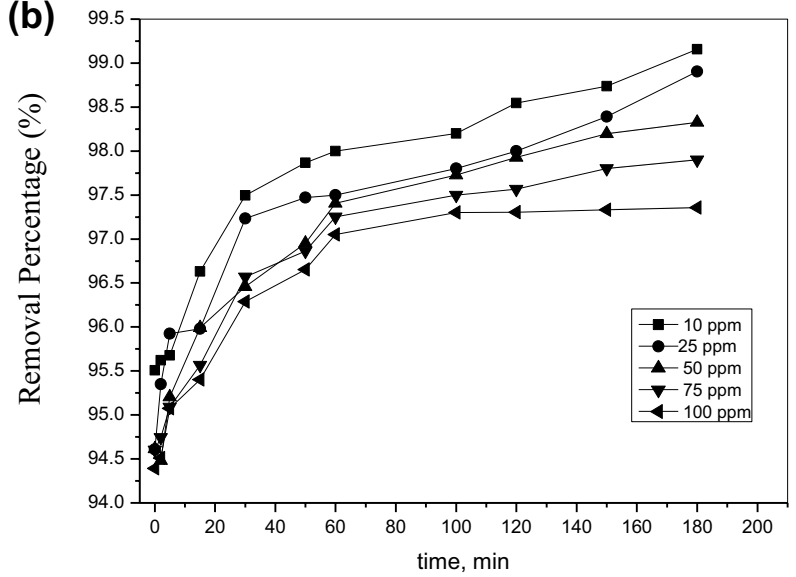

(d)

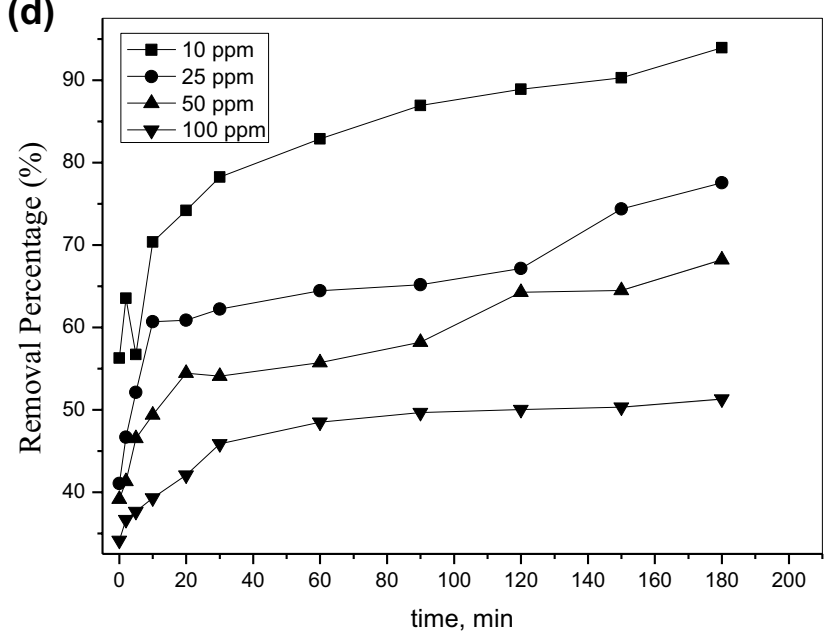

Fig. 4 Effect of initial dye concentration on the removal percentage of a $\mathrm{RR}$ onto $\mathrm{H} 6\left(300{ }^{\circ} \mathrm{C}\right)$ at equilibrium, $\mathbf{b} \mathrm{RR}$ on $\mathrm{H} 6\left(300{ }^{\circ} \mathrm{C}\right)$ at $\mathrm{pH}=7$ at different times, $\mathbf{c} \mathrm{MB}$ onto $\mathrm{H} 6\left(300{ }^{\circ} \mathrm{C}\right)$ at $\mathrm{pH}=11$ at different times, and $\mathbf{d} \mathrm{MB}$ onto $\mathrm{H} 8\left(300{ }^{\circ} \mathrm{C}\right)$ at $\mathrm{pH}=11$ at different times

and $\mathrm{H} 8$ solid calcined at $300{ }^{\circ} \mathrm{C}$. It is clear from Fig. 4 that there is an increase in the percentage of adsorption of $\mathrm{MB}$ and/or RR by decreasing dye concentrations in the solution. The uptake of $\mathrm{H} 6$ for $10 \mathrm{ppm}$ of dye concentration reached to 99.6 and $98.1 \%$ for RR and MB, respectively. These results may be due to the saturation of adsorption sites on the surface of adsorbent. Adsorption removal of RR decreased in small value by increasing the dye concentration. The uptake of RR above $50 \mathrm{ppm}$ was decreased by $5 \%$ than the other. But MB adsorption decreases significantly with large value. By noticing Fig. 4c, d, we can see that increasing the initial concentration of MB from 10 to $100 \mathrm{ppm}$ in the presence of $\mathrm{H} 6$ and $\mathrm{H} 8$ led to significant decrease in the adsorption removal percentage. This difference in adsorption behavior may be related to the difference in the nature of anionic and cationic dyes. However, the initial dye concentration will be constant at $50 \mathrm{ppm}$ in all the experiments of adsorption of $\mathrm{RR}$ and/or MB dyes for different prepared solids.

\section{Effect of calcination temperature}

Adsorption of RR on the $\mathrm{H} 6$ and $\mathrm{H} 8$ adsorbents calcined at $300,500,700{ }^{\circ} \mathrm{C}$ were studied at initial dye concentration $50 \mathrm{ppm}, \mathrm{pH} 3$, temperature $25^{\circ} \mathrm{C}$ and an adsorbent dose $50 \mathrm{mg}$. Figure $5 \mathrm{a}, \mathrm{b}$ shows the percentage of dye uptake plotted against time (min). We concluded from this figure that: (1) the removal percentage of RR reaches equilibrium at 2 min only on $\mathrm{H} 6$ and $\mathrm{H} 8$ samples calcined at 300 and $500{ }^{\circ} \mathrm{C}$ and reached in 5-7 min for adsorbents calcined at $700{ }^{\circ} \mathrm{C}$. (2) The removal of RR at 300 and $500{ }^{\circ} \mathrm{C}$ has the same values (c.f. Fig. 5a). The removal qualification of RR dye at 300 and $500{ }^{\circ} \mathrm{C}$ was the highest $(=100 \%)$. This result can be discussed by observing the decrease in the crystallite size of the active phase $\mathrm{CoFe}_{2} \mathrm{O}_{4}$ (c.f. Table 1), the appearance of excess active sites for adsorption process as $\mathrm{C}$ phase and increasing the $S_{\mathrm{BET}}$ for $\mathrm{H} 6$ and $\mathrm{H} 8$ samples calcined at 300 and $500{ }^{\circ} \mathrm{C}$ (c.f. Table 2). (3) There is a small decrease 

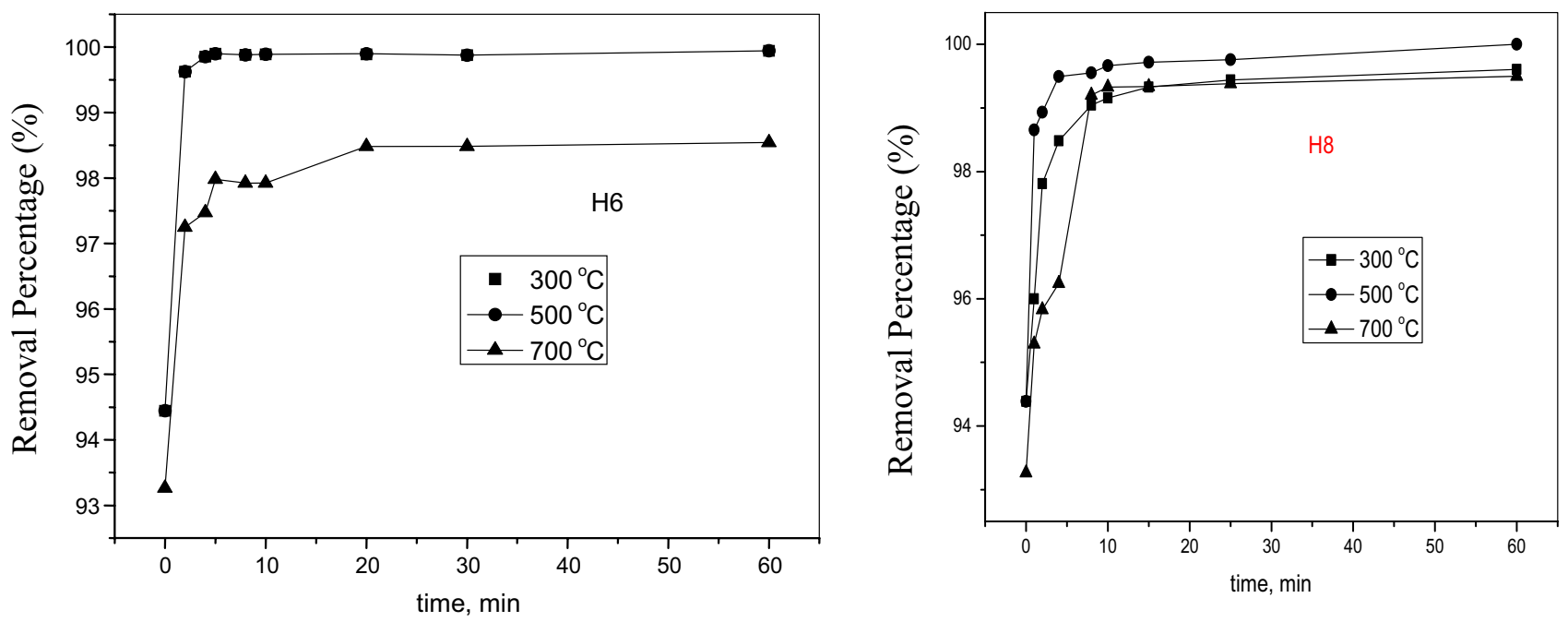

Fig. 5 Effect of calcination temperature on the removal percentage of RR by H6 and H8 nanomaterials calcined at different temperatures

in the removal of RR by increasing the calcination temperature to $700{ }^{\circ} \mathrm{C}$ over $\mathrm{H} 6$ sample. The decrease of removal of $\mathrm{H} 6700{ }^{\circ} \mathrm{C}$ might be due to the increasing mean pore radius $\left(r^{-}\right)$compared to $r^{-}$of $\mathrm{H} 6300{ }^{\circ} \mathrm{C}$ and decreasing its surface area (c.f. Table 2). (4) On the other hand, in $\mathrm{H} 8$ solid, further increase in the calcination temperature to $700{ }^{\circ} \mathrm{C}$ led to a small increase in the time required to reach equilibrium. (5) In addition, the removal efficiency over $\mathrm{H} 8\left(700^{\circ} \mathrm{C}\right)$ was as the same as the solid calcined at 300 and $500{ }^{\circ} \mathrm{C}$, where the RR uptake attained $99.6 \%$. This high performance could be attributed to a significant increase in the $S_{\mathrm{BET}}$ of $\mathrm{H} 8\left(700^{\circ} \mathrm{C}\right)$ comparing with $\mathrm{H} 8\left(300^{\circ} \mathrm{C}\right)$.

Therefore, the adsorption efficiency of $\mathrm{H} 6$ is at $300 \sim 500>700{ }^{\circ} \mathrm{C}$, but in the $\mathrm{H} 8$, the efficiency is not affected by increasing calcination temperature.

Finally, we can conclude that both of $\mathrm{H} 6$ and $\mathrm{H} 8$ calcined at $300{ }^{\circ} \mathrm{C}$ and $500^{\circ} \mathrm{C}$ are more preferable for dye uptake than calcined at $700{ }^{\circ} \mathrm{C}$ in terms of energy saving. Therefore, in the next sections, we will concern in our study with studying over $\mathrm{H} 6$ and $\mathrm{H} 8$ calcined at $300{ }^{\circ} \mathrm{C}$ and $500{ }^{\circ} \mathrm{C}$ adsorbents.

\section{Effect of solution $\mathrm{pH}$}

The adsorption of RR and MB on $\mathrm{H} 6$ and $\mathrm{H} 8$ calcined at $500{ }^{\circ} \mathrm{C}$ was studied in different $\mathrm{pH}$ range of dye solution (3-11) as shown in Fig. 6a-e. Figure 6 shows that: (1) the percentage of dye removal of RR increases by decreasing the $\mathrm{pH}$ value. (2) The removal of $\mathrm{RR}$ at $\mathrm{pH} 3$ at equilibrium reached to $(100 \%, 48.19 \mathrm{mg} / \mathrm{g})$ in both $\mathrm{H} 8$ and $\mathrm{H} 6$ solids. But, when the $\mathrm{pH}$ is increased to 5 , the maximum RR adsorption decreased to $98 \%$, and $97 \%$ for $\mathrm{H} 8$ and $\mathrm{H} 6$ solids, respectively. Further decrease occurred in removal with increasing $\mathrm{pH}$ value to $\geq 7$. In the same manner $\mathrm{pH} 11$, the removal reached $80 \%$ and $92.8 \%$ in $\mathrm{H} 8$ and $\mathrm{H} 6$ solids, respectively (Fig. 6a-c). (3) On the other hand, the behavior is completely different in studying the effect of $\mathrm{pH}$ of $\mathrm{MB}$ dye solution on the removal over $\mathrm{H} 6$ and $\mathrm{H} 8$ adsorbents calcined at $500{ }^{\circ} \mathrm{C}$. This means that the adsorption capacity of $\mathrm{MB}$ increases by increasing $\mathrm{pH}$ value from 3 to 11 as shown in Fig. 6d-e. The previous behavior can be related to the adsorption mechanism.

Explaining the mechanism of interaction between $\mathrm{H} 6$ and $\mathrm{H} 8\left(500{ }^{\circ} \mathrm{C}\right)$ adsorbents and the applied dyes requires determining the surface charges by Zeta-potential measurements. The Zeta-potential of $\mathrm{H} 6$ and $\mathrm{H} 8\left(500{ }^{\circ} \mathrm{C}\right)$ was drawn as shown in Fig. $7 \mathrm{a}-\mathrm{b}$. It was observed that $\mathrm{H} 8$ and $\mathrm{H} 6\left(500^{\circ} \mathrm{C}\right)$ solids have negative $Z$-potential at $\mathrm{pH} \geq 7$, indicating that they possessed negative surface charges, so, the uptake of anionic dye (RR) decreased but in the case of cationic dye (MB) increased simultaneously at this high $\mathrm{pH}$ value. On the contrary, the surface became positively charged at $\mathrm{pH}<6$ and unlike the above in the removal of RR and MB clearly. Hence, at $\mathrm{pH} 3$, a significantly high electrostatic attraction takes place between the positively charged surface of the $\mathrm{H} 6$ or $\mathrm{H} 8\left(500{ }^{\circ} \mathrm{C}\right)$ and anionic dye RR. On the other side, at $\mathrm{pH} 11, \mathrm{MB}$ makes high electrostatic attraction with the negatively charged surface of solids.

The $\mathrm{pH}_{\mathrm{pzc}}$ of $\mathrm{H6}$ and $\mathrm{H} 8$ is tabulated in Table 2, last column. It was found that $\mathrm{pH}_{\mathrm{pzc}}$ values of $\mathrm{H} 6$ and $\mathrm{H} 8$ are 6.4 and 5.9, respectively. It is known that, as the $\mathrm{pH}$ increases $\left(>\mathrm{pH}_{\mathrm{pzc}}\right)$, the amount of sites have positive charged decreases and the number of sites have negative charged increases. Applying dye adsorption over both adsorbents at $\mathrm{pH}=11>\mathrm{pH}_{\mathrm{pzc}}$, the surface becomes negatively charged due to the presence of functional group such as $\mathrm{OH}^{-}$group, $\mathrm{MB}$ cationic dye adsorption is more preferable than anionic dye (RR) adsorption (Fig. 6a, d). Whereas, the surface turns out into positively charged at $\mathrm{pH}=3<\mathrm{pH}_{\mathrm{pzc}}$, However, anionic 

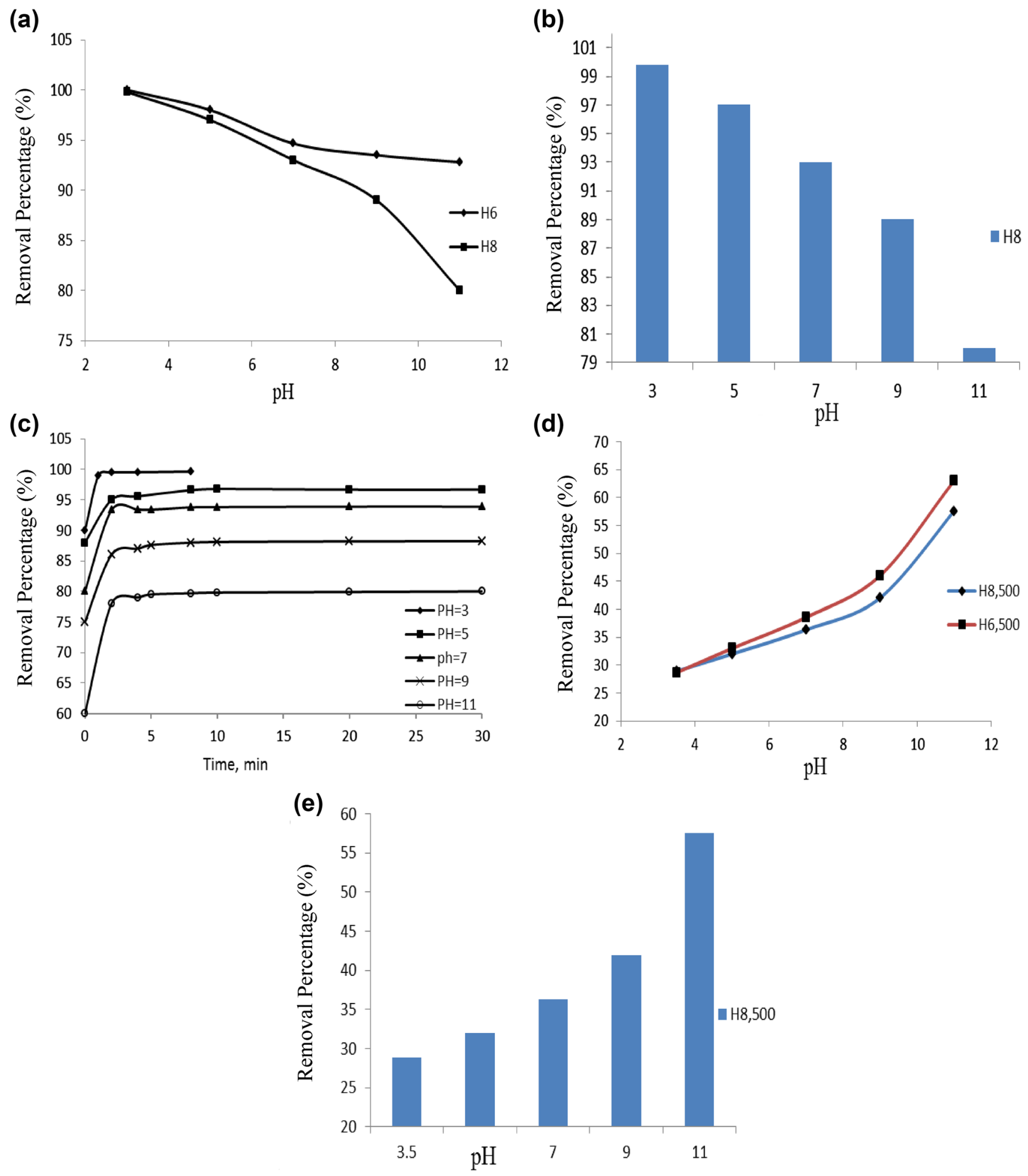

Fig. 6 Effect of solution pH on the adsorption of a RR by H6 and H8 b RR by H8 c RR by H8 d MB by H6 and H8 e MB by H8 calcined at $500{ }^{\circ} \mathrm{C}$

dye RR is favored. According to the previous results, at high $\mathrm{pH}$ values $\geq 7$, the adsorbents surface is negatively charged and the decreasing (RR) adsorption of dye due to the electrostatic repulsive occurs as expected. In the same way, the decrease of adsorption (MB) cationic dye molecules happens at low $\mathrm{pH}<7$ because of electrostatic repulsive. 
(a)

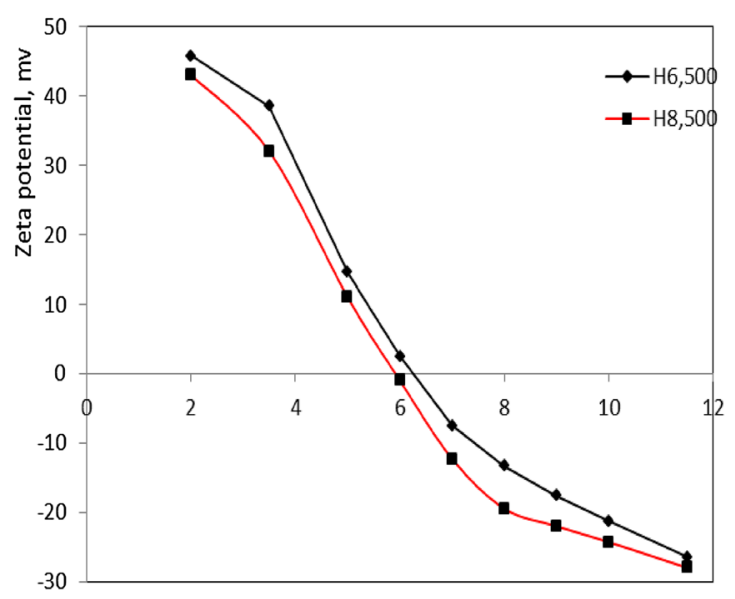

(b)

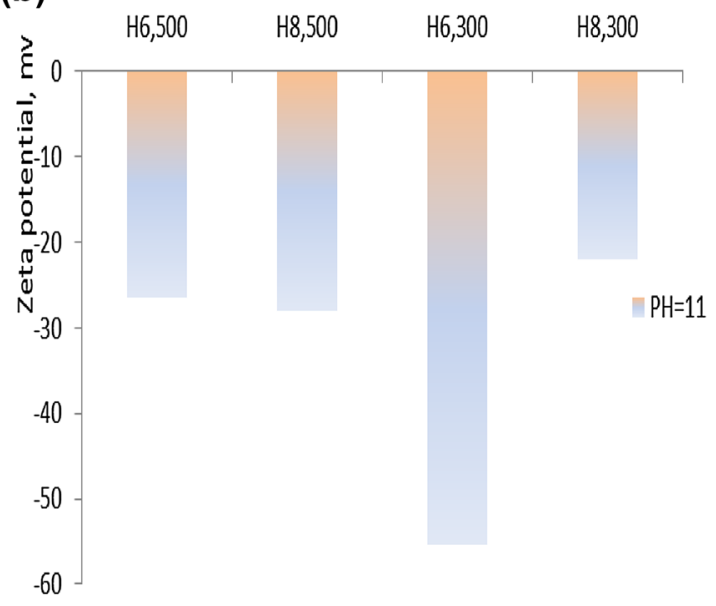

Fig. 7 a The Zeta-potential of $\mathrm{H} 8$ and $\mathrm{H} 6\left(500{ }^{\circ} \mathrm{C}\right)$ at different $\mathrm{pH}, \mathbf{b}$ the Zeta-potentials of different solids at $\mathrm{pH} 11$

Therefore, the optimum $\mathrm{pH}$ for higher MB and RR removal from aqueous solution is 3 and 11 , respectively, over different solids.

\section{Effect of time and intercalation of $\mathrm{HA}$}

Figure 8a-c shows the effect of solids' modification with HA on the efficiency of the as-prepared solids calcined at 300 and $500{ }^{\circ} \mathrm{C}$ toward removal of RR dye as a function of time (at certain conditions as reported in "Experimental" section). According to Fig. 8a-c, it is clear that (1) the removal of $\mathrm{RR}$ dye at $\mathrm{pH}=3$ after 2 min for $\mathrm{H} 6$ and $\mathrm{H} 8$ reached equilibrium(very quickly) with removal 99.8 and $94 \%$ for solids calcined at 300 and $500{ }^{\circ} \mathrm{C}$, respectively. (2) But, the $R \%$ of the unmodified solids P6 and P8 takes approximately 10 min to arrive to equilibrium. (3) A significant decrease in the RR removal percentage (at $\mathrm{pH} 7$ ) onto $\mathrm{P} 6$ and $\mathrm{P} 8$ calcined at $500{ }^{\circ} \mathrm{C}$, which attained 45.5 and $61.7 \%$ less than treated solids, respectively. These decreases in anionic dye removal may have been due to an increase in the negative surface charge of these adsorbents due to the high value of the dye solution $\mathrm{pH}=7\left(>\mathrm{pH}_{\mathrm{pzc}}\right)$, where $\mathrm{pH}_{\mathrm{pzc}}$ for $\mathrm{P} 6$ and $\mathrm{P} 8$ calcined at $500{ }^{\circ} \mathrm{C}$ was 6.5 and 6.7 , respectively, as obtained in Zeta-potential results [34]. The apparent decrease may be related with the absence of $\mathrm{CoFe}_{2} \mathrm{O}_{4}$ active sites, increasing the mean pore radius and/or decreasing the surface area (Tables 1, 2). (4) P6 and P8 calcined at $300{ }^{\circ} \mathrm{C}$, the uptake decrease attained to 33.3 and $9 \%$, respectively. This decrease in dye removal may be related to decreasing its surface area $\left(S_{\mathrm{BET}}=18.4 \mathrm{~m}^{2} / \mathrm{g}\right.$, c.f. Table 2$)$. On the other hand, the decrease in uptake over P8 that calcined at $300{ }^{\circ} \mathrm{C}$ does not exceed $9 \%$. This may be related to the presence of various active sites as $\mathrm{Fe}_{2} \mathrm{O}_{3}, \mathrm{CoFe}_{2} \mathrm{O}_{4}$, and $\mathrm{C}$ or decreasing the crystallite size of the active sites $\left(\mathrm{CoFe}_{2} \mathrm{O}_{4}\right)$ which attained to $3 \mathrm{~nm}$ (c.f. Table 1), which makes a certain push to the surface to improve its absorbance quality despite the limited value of its surface area. (5) Increasing $\mathrm{pH}$ value of the precipitated solution reaching to $\mathrm{pH} 7$ for $\mathrm{H} 6$ and $\mathrm{H} 8$ calcined at $300{ }^{\circ} \mathrm{C}$ led to a minor decrease in the dye removal percentage, but no change was observed for other $\mathrm{H} 6$ and $\mathrm{H} 8$ calcined at $500^{\circ} \mathrm{C}$, where the two curves of RR uptake are coincided.

To show further the effect of changing $\mathrm{pH}$ of the $\mathrm{CoFe}_{2} \mathrm{O}_{4}$ precipitated modified with $\mathrm{HA}$ through co-precipitation preparation on the surface charging, Fig. $8 \mathrm{~d}$ shows the removal of MB dye at equilibrium over $\mathrm{H} 6$ and $\mathrm{H} 8\left(300^{\circ} \mathrm{C}\right)$ at different dye concentrations $(\mathrm{pH} 11)$. This figure refers that there is a small decrease in the removal of MB for $\mathrm{H} 8$ comparing with H6. On the other side, there is an increase in the MB removal for $\mathrm{H} 6$ solids higher than $\mathrm{H} 8$ solids calcined at $300{ }^{\circ} \mathrm{C}$. This result may be explained by noticing Fig. $7 \mathrm{~b}$, which shows that at $\mathrm{pH} 11$, the Zeta-potential of $\mathrm{H6}$ is higher than $\mathrm{H} 8$, which attained $60.3 \%$ increase in the negatively surface charges. This result reflects the reason of the previous observations in Fig. 8d, which shows the decrease in $\% R$ of $\mathrm{MB}$ for $\mathrm{H} 8$. However, under highly alkaline conditions, deprotonation on the surface of $\mathrm{H} 6$ forms $\mathrm{OH}^{-}$and the electrostatic interaction between H6, cationic dye, and the increase in the negative charges causes the approach of cationic dye to H6, leading to an increase in the adsorption efficiency. But the process is totally different in treated solids calcined at $500{ }^{\circ} \mathrm{C}$, and the negative surface charges are nearly the same. This result indicates that changing the surface charge of the adsorbents associated with the presence of HA and/or calcination temperature influences the type of concentration of electric charges and the electrostatic interactions among particles [34].

Therefore, we can conclude that the efficiency of RR dye uptake was significantly improved by intercalation HA through co-precipitation method and this emphasizes the role of acidic character of functional groups as carboxyl and 

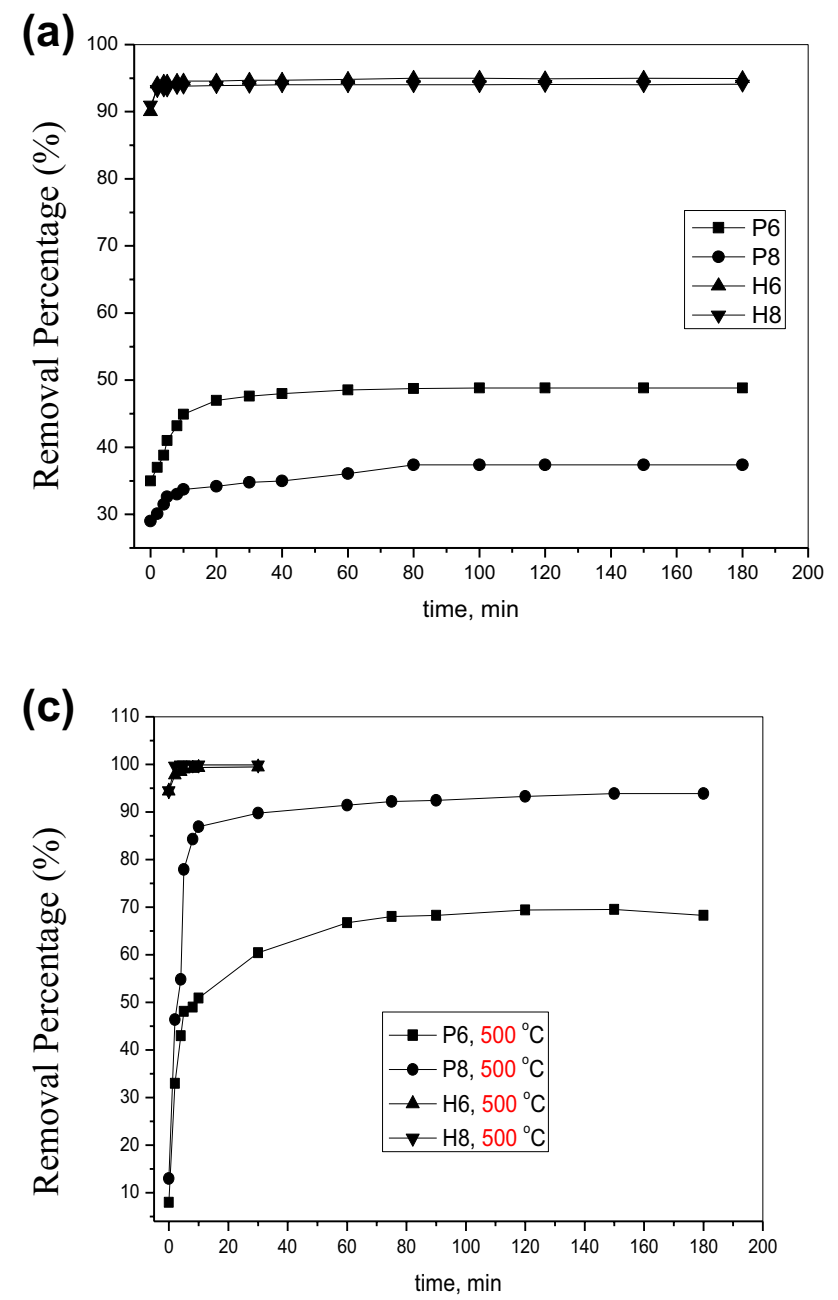

Fig. 8 Effect of contact time and intercalation on the removal percentage and adsorption capacity of RR by unmodified and modified nanomaterials $\mathbf{a}, \mathbf{b}$ (dye conc. $=50 \mathrm{ppm}$, and $\mathrm{pH}=3$ ) calcined at

phenolic groups which resulted in increase in the percentage of positive electric charges at the surface of the adsorbent. Therefore, $\mathrm{pH}_{\mathrm{pzc}}$ of $\mathrm{H} 6 \mathrm{H} 8$ was lower than unmodified one (Zeta-potential results, Table 2). However, at $\mathrm{pH} 3<\mathrm{pH}_{\mathrm{pzc}}$, $100 \%$ uptake of RR through 2 min can be as a result of the electrostatic attraction between the positive surface charge of H6, H8 solids and negatively charged dye molecule, decreasing the crystallite size of $\mathrm{CoFe}_{2} \mathrm{O}_{4}$ active phase accompanying with increasing carbon active sites, and/or increasing the surface area.

Therefore, it can be noticed that the RR removal \% increases as: $\mathrm{H} 8 \approx \mathrm{H} 6>\mathrm{P} 6>\mathrm{P} 8$ calcined at $500{ }^{\circ} \mathrm{C}$ but the removal for both dyes $\mathrm{H} 6 \geq \mathrm{H} 8>\mathrm{P} 8>\mathrm{P} 6$ calcined at $300^{\circ} \mathrm{C}$.

It is known that HA is highly acidic organic matter by reason of carboxylic and phenolic groups, with minimum liberality from the aliphatic- and enolic-OH groups. Its total acidity ranged from 1 to $>14 \mathrm{~mol} / \mathrm{kg}$ and the $\mathrm{pKa}$ for most acidic
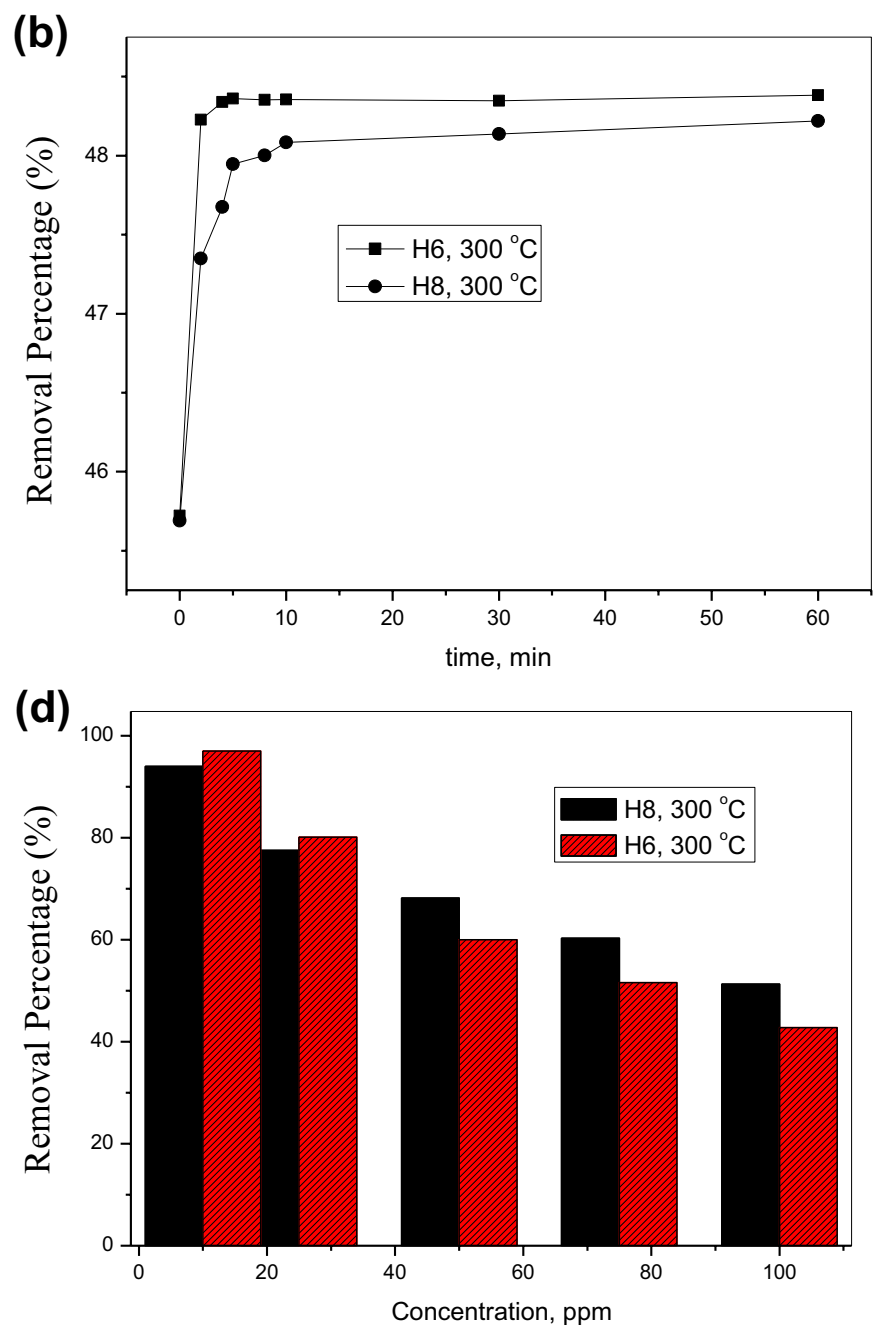

$300{ }^{\circ} \mathrm{C}$, $\mathbf{c}$ (dye conc. $=50 \mathrm{ppm}$, and $\mathrm{pH}=7$ ) calcined at $500{ }^{\circ} \mathrm{C}$, and d on the removal \% of $\mathrm{MB}$ onto $\mathrm{H} 6$ and $\mathrm{H} 8$ at different dye conc., $\mathrm{pH}=11$

functional groups is between 5 and 7 [43]. This indicates high acidic character, so, many charged and highly polar functional groups like carboxyl groups $(\mathrm{COOH})$ release hydrogen ions, resulting in increase in the percentage of positive electric charges at the surface of the adsorbent. Therefore, the enhanced uptake of RR at $\mathrm{pH} 7$ (natural $\mathrm{pH}$ ) can be attributed to the electrostatic forces of attraction between the positive surface charge of the $\mathrm{H} 6$ and $\mathrm{H} 8$ solids and negatively charged dye molecule. Conversely, at $\mathrm{pH}>9$, the electrostatic repulsion force will be occur and decreasing the removal of dye.

The previous results referred that the intercalation of HA can improve the colloidal efficiency, relying on the chemical adsorption conditions (e.g., pH), the properties of particles (e.g., PZC) and the control of $\mathrm{pH}$ through co-precipitation step.

Finally, we can say that the synthesized samples using $\mathrm{HA}$ in co-precipitation process were shown to be hopeful 
adsorbents for the removal of textile dyes from aqueous solutions. This is further emphasized by comparing the maximum adsorption capacity of textile dyes with different adsorbents with $q_{\max }$ of treated solids as shown in Table 4.

\section{Adsorption isotherms}

Four models for equilibrium adsorption isotherms were applied [40]. The models are Langmuir, Freundlich, Temkin, and Dubinin-Radushkevich (D-R). To examine the best fitting model, standard error and correlation coefficients $\left(R^{2}\right)$ were used. Different isotherm parameters, correlation coefficients, and standard errors are listed in Table 3.

\section{Langmuir isotherm}

The Langmuir model is employed and the values of $\mathrm{q}_{\max }$ were determined by applying the linear form of Langmuir equation [39, 40, 44].

The plots of $C_{\mathrm{e}} / q_{\mathrm{e}}$ vs. $C_{\mathrm{e}}$ for adsorption RR and/or MB over $\mathrm{H} 6$ and $\mathrm{H} 8$ solids calcined at $300{ }^{\circ} \mathrm{C}$ are presented in Fig. 9a. The value of correlation coefficients, $R^{2}(0.993-0.995)$ and lower value of standard error $\chi^{2}$ (0.011-0.017) for RR and MB were observed referring that the adsorption data followed the Langmuir isotherm model (c.f. Table 3).

$R_{\mathrm{L}}$ is the dimensionless separation factor at equilibrium, which is utilized to assess if $\left(0>R_{\mathrm{L}}<1\right)$, the adsorption process will be satisfactory, but if $\left(R_{\mathrm{L}}=1\right)$ or $\left(R_{\mathrm{L}}>1\right)$, the adsorption process will be unfavorable or irreversible. $R_{\mathrm{L}}$ was calculated using the following equation (7):

$R_{\mathrm{L}}=\frac{1}{1+C_{0} K_{\mathrm{L}}}$.
The values of $R_{\mathrm{L}}(0.013-0.112)$ for $\mathrm{RR}$ and $0.025-0.348$ for MB dye were obtained and are listed in Table 3. The values of $Q_{\max }$ were $277.77 \mathrm{mg} / \mathrm{g}$ for adsorbing RR over H6 $\left(300{ }^{\circ} \mathrm{C}\right)$, but for adsorbing MB over $\mathrm{H} 6$ and $\mathrm{H} 8$ $\left(300{ }^{\circ} \mathrm{C}\right)$ were 27.01 and $34.36 \mathrm{mg} / \mathrm{g}$, respectively.

The efficiency of the prepared $\mathrm{H} 6$ and $\mathrm{H} 8$ for dyes adsorption was further investigated by a comparison of the highest adsorption capacities of RR and MB over modified $\mathrm{CoFe}_{2} \mathrm{O}_{4}$ adsorbents in this work with the other different adsorbents on the literature as shown in Table $4[34,39$, 42, 45-59]. It is clear that $\mathrm{CoFe}_{2} \mathrm{O}_{4}$ modified possesses the highest maximum adsorption capacity for RR and MB. This directed that overall adsorption capacity of H6 and $\mathrm{H} 8$ is rather than reported adsorbents, which reflects potential utility for the prepared adsorbents utilization in the applied dye removal.

\section{Freundlich isotherm}

Freundlich equation was employed to calculate the Freundlich isotherm parameters $[35,36]$. The plots of $\log q_{\mathrm{e}}$ vs. $\log C_{\mathrm{e}}$ for the adsorption of RR and MB onto H6 H8 solids calcined at $300{ }^{\circ} \mathrm{C}$ are shown in Fig. 9b, d. The Freundlich parameters are listed in Table 3. The less than unity values of $1 / n$ referred to satisfactory adsorption process. The values of correlation coefficient $\left(R^{2}\right)(0.92-0.95)$ for both dyes showed that Freundlich isotherm was not proper to designate the data of the experiment.

\section{Dubinin-Radushkevich (D-R) isotherm}

Dubinin-Radushkevich was employed to predict whether the nature of adsorption procedure is physical or chemical [42, $60,61]$. The linear form of D-R equation is given as (Eq. 8) $[42,45,62]$ :

Table 3 Adsorption isotherms parameters for adsorption of RR and MB dyes onto $\mathrm{H} 6$ and $\mathrm{H} 8$ calcined at $300{ }^{\circ} \mathrm{C}$

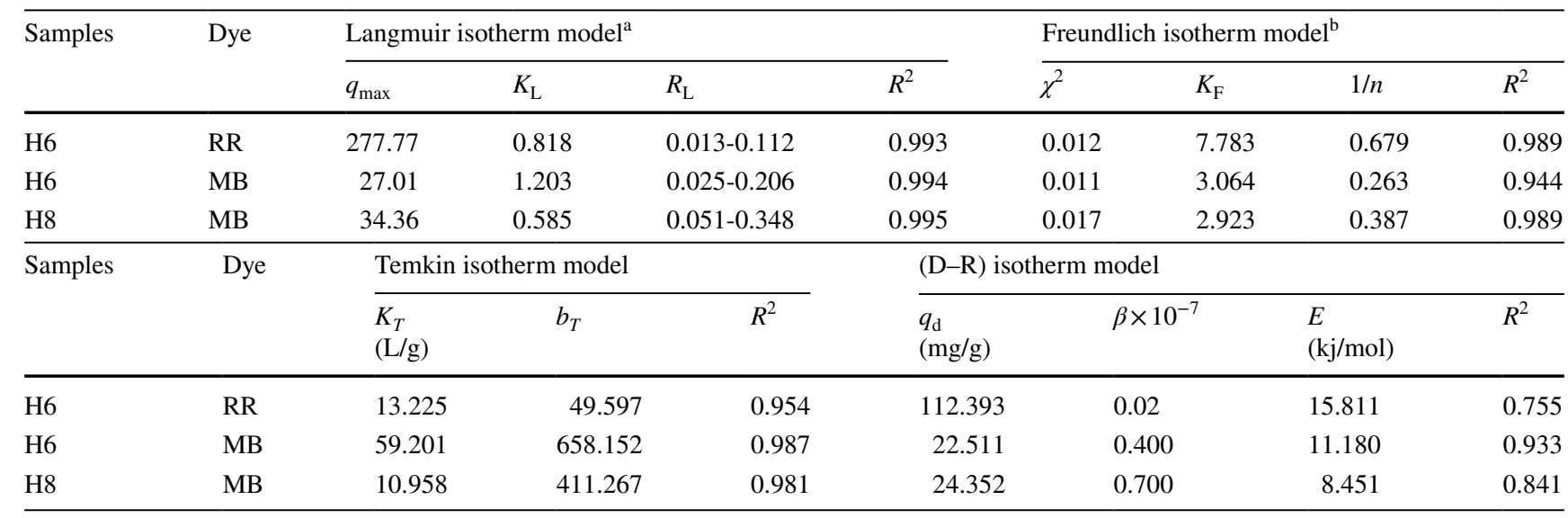

${ }^{\text {a Langmuir equation }} C_{\mathrm{e}} / q_{\mathrm{e}}=C_{\mathrm{e}} / q_{\max }+1 /\left(K_{\mathrm{L}} \cdot q_{\max }\right)[35,36,40]$

${ }^{\mathrm{b}}$ Freundlich equation $\log q_{\mathrm{e}}=\log K_{\mathrm{f}}+1 / n \log C_{\mathrm{e}}[35,36]$ 
(a)

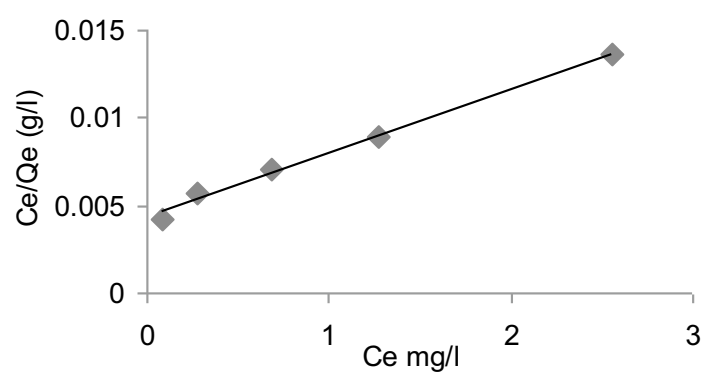

(c)

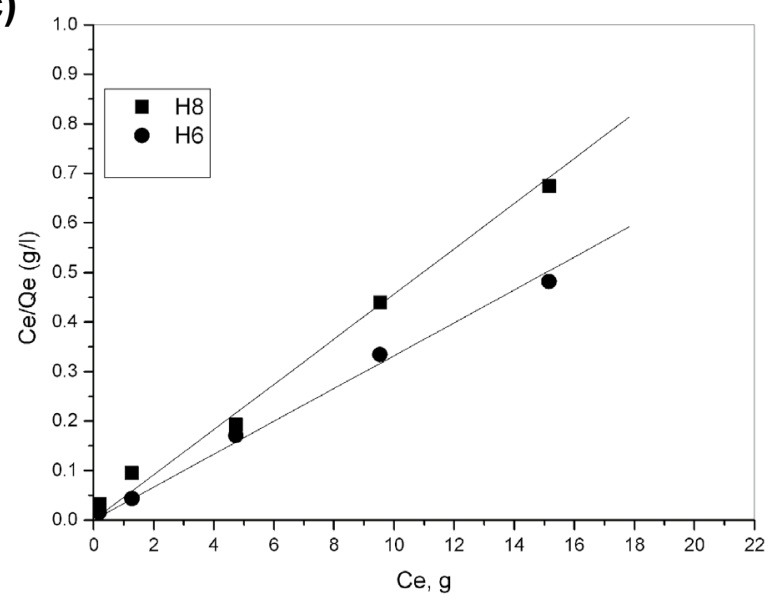

(e)

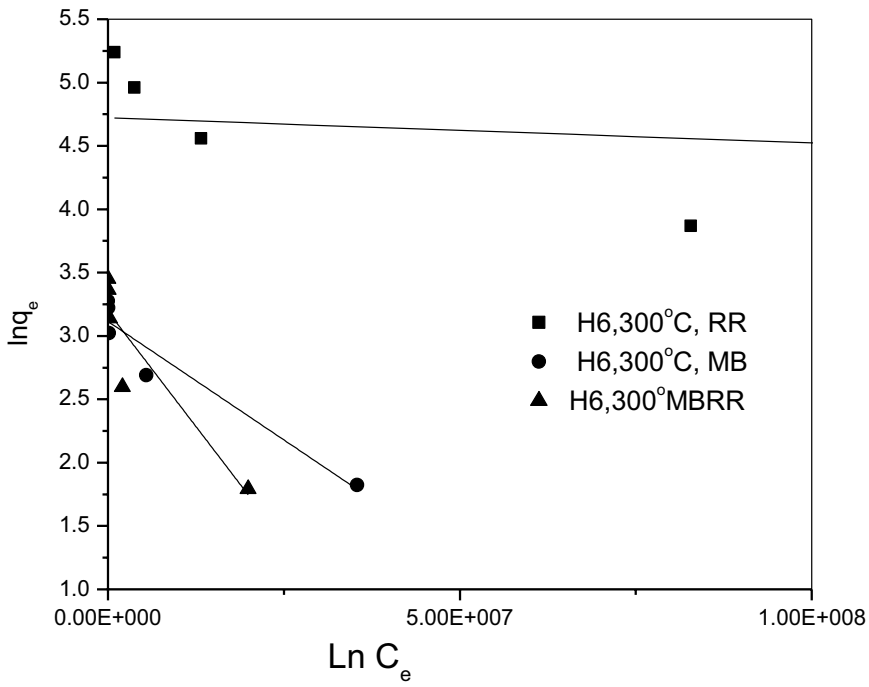

Fig. 9 a Langmuir isotherms, b Freundlich isotherms for RR dye adsorption onto $\mathrm{H} 6\left(300{ }^{\circ} \mathrm{C}\right)$ nanomaterial calcined at $300{ }^{\circ} \mathrm{C}$, c Langmuir isotherms, $\mathbf{d}$ Freundlich isotherms for $\mathrm{MB}$ dye adsorption (b)

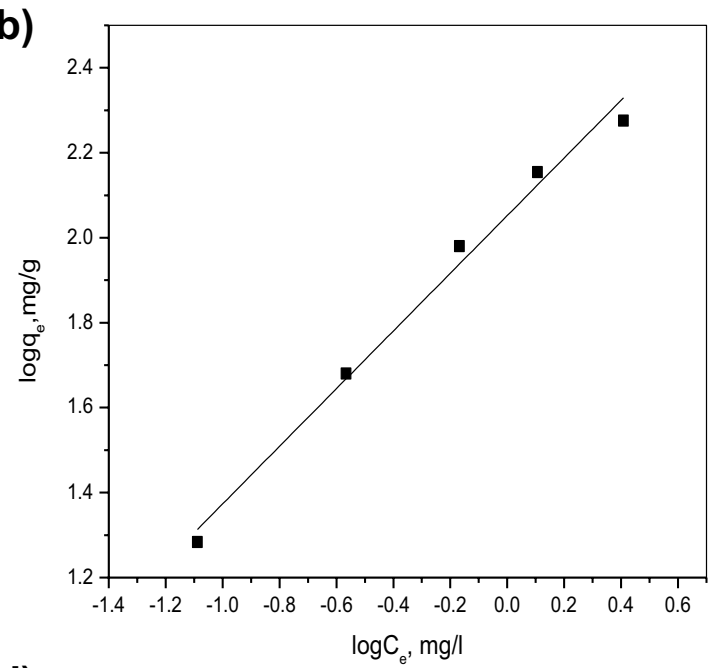

(d)

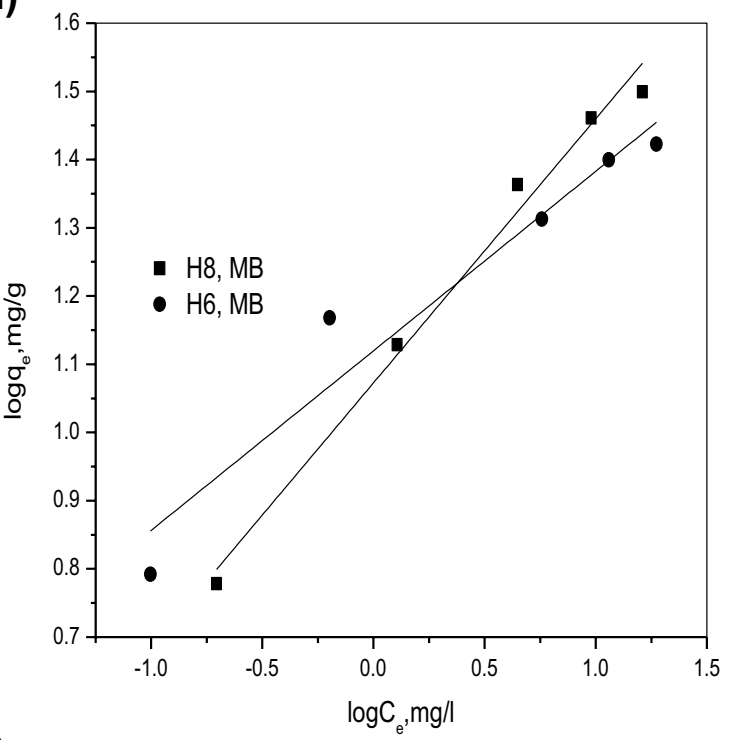

(f)

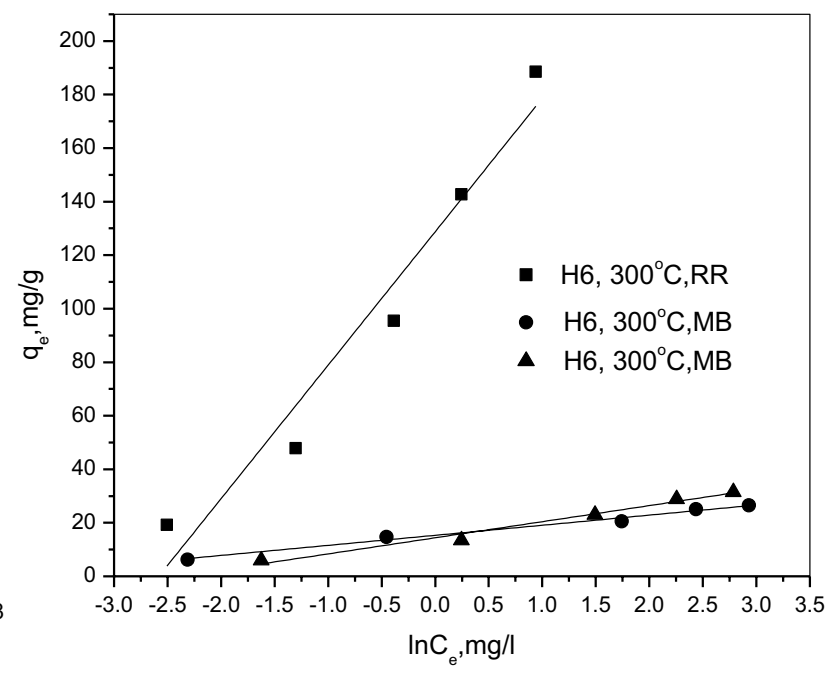

onto H6 $\left(300{ }^{\circ} \mathrm{C}\right)$ and $\mathrm{H} 8\left(300{ }^{\circ} \mathrm{C}\right)$ nanomaterials, e Dubinin-Radushkevich (D-R) isotherm, and f Temkin isotherm 
Table 4 Comparison of maximum adsorption capacity of textile dyes with different adsorbents

\begin{tabular}{|c|c|c|c|c|}
\hline No. & Adsorbent & Dye & $\begin{array}{l}\text { Max. adsorption } \\
\text { capacity }(\mathrm{mg} / \mathrm{g})\end{array}$ & References \\
\hline 1 & Neem saw dust & & 3.6 & [45] \\
\hline 2 & Beer brewery waste & MB & 4.9 & [46] \\
\hline 3 & Cow dung ash & & 5.3 & {$[47]$} \\
\hline 4 & Coir pith carbon & & 5.9 & [48] \\
\hline 5 & $\begin{array}{l}\text { Citric acid (CA)/B-cyclodextrin (CD)/2-dimethyl- } \\
\text { aminoethylmethacrylate (PDMAEMA) }\end{array}$ & & 166 & [49] \\
\hline 6 & Chitosan $/ \mathrm{Fe}_{3} \mathrm{O}_{4} /$ graphene oxide nanocomposite & & 30 & {$[50]$} \\
\hline 7 & Magnetic g- $\mathrm{Fe}_{2} \mathrm{O}_{3} / \mathrm{SiO}_{2}(\mathrm{M}-\mathrm{gFS})$ nanocomposite & & 27 & {$[51]$} \\
\hline 8 & $\mathrm{CoFe}_{2} \mathrm{O}_{4} / \mathrm{H} 8300^{\circ} \mathrm{C}$ & & 34 & Present study \\
\hline 9 & $\mathrm{CoFe}_{2} \mathrm{O}_{4} / \mathrm{H} 6300^{\circ} \mathrm{C}$ & & 27 & Present study \\
\hline 10 & $\mathrm{TiO}_{2}$-loaded chitosan-grafted polymethyl aniline & $\mathrm{RR}$ & 110 & {$[52]$} \\
\hline 11 & $\mathrm{Fe}_{2} \mathrm{O}_{3} / \mathrm{MgO}$ & & 37 & {$[53]$} \\
\hline 12 & $\mathrm{MgO}$ nanomaterials & & 77 & [39] \\
\hline 13 & Activated sawdust & & 8 & {$[54]$} \\
\hline 14 & Commercial charcoal & & 0.1 & {$[54]$} \\
\hline 15 & Activated carbon & & 60 & {$[55]$} \\
\hline 16 & Fly ash & & 59 & {$[56]$} \\
\hline 17 & Coconut mesocarp & & 4 & {$[57]$} \\
\hline 18 & Wood residues & & 0.7 & {$[57]$} \\
\hline 19 & Polyaniline/cerium oxide & & 19 & {$[58]$} \\
\hline 20 & $\mathrm{CeO}_{2}-\mathrm{Fe}_{2} \mathrm{O}_{3}-\mathrm{Al}_{2} \mathrm{O}_{3}\left(\mathrm{CFA}_{\mathrm{H}}\right)$ & & 77 & {$[42]$} \\
\hline 21 & $\mathrm{CoFe}_{2} \mathrm{O}_{4} / \mathrm{H} 6300^{\circ} \mathrm{C}$ & & 278 & Present study \\
\hline 22 & $\mathrm{CoFe}_{2} \mathrm{O}_{4}\left(\mathrm{~F} 8,300^{\circ} \mathrm{C}\right)$ & & 42 & [34] \\
\hline
\end{tabular}

$\ln q_{\mathrm{e}}=\ln q_{\mathrm{d}}-\beta \varepsilon^{2}$,

$\varepsilon=R T \ln \left(1+1 / C_{\mathrm{e}}\right)$,

where $q_{\mathrm{d}}$ is theoretical adsorption capacity $(\mathrm{mg} / \mathrm{g}), R$ is gas constant, $T$ is temperature, $\beta$ is $\mathrm{D}-\mathrm{R}$ isotherm constant, and $\varepsilon=$ Polanyi potential. The plots of $\ln q_{\mathrm{e}}$ vs. $\varepsilon^{2}$ (Fig. 9e) yielded the parameters of D-R isotherm. The apparent energy of adsorption ( $E \mathrm{kj} / \mathrm{mol}$ ) was calculated using the following relationship (Eq. 9):

$E=1 /(2 \beta)^{1 / 2}$,

where $E, q_{\mathrm{d}}, \beta$ and $R^{2}$ are listed in Table 3 . The results show poor correlation coefficient and the adsorption process of both dyes is chemical in nature because the $(E)$ values were between 8 and $16 \mathrm{kj} / \mathrm{mol}$.

\section{Temkin isotherm}

The linear form of Temkin isotherm model is given by the following equation [63-65]:

$q_{\mathrm{e}}=R T / b_{T} \ln K_{T}+R T / b_{T} \ln C_{\mathrm{e}}$, where $b_{T}(\mathrm{kj} / \mathrm{mol})$ is Temkin constant which is related to the heat of sorption, and $K_{T}(\mathrm{~L} / \mathrm{g})$ is the equilibrium-binding constant concerning to the maximum binding energy. We can get $b_{T}$ and $K_{T}$ from the slope and intercept of plotting $q_{\mathrm{e}}$ versus $\ln C_{\mathrm{e}}$, which are recorded in Table 3.

In the comparison of the correlation coefficients $R^{2}$ and non-linear $\chi^{2}$ values for the applied isotherms, the Langmuir isotherms showed the highest correlation coefficient (RR 0.993), (MB 0.994-0.995) and lower $\chi^{2}$ values (RR 0.010 and MB 0.011-0.017) appeared to be the best appropriate model for adsorption of $\mathrm{RR}$ and $\mathrm{MB}$ onto H6 and $\mathrm{H} 8$ solids, which showed that sites of adsorption were energetically homogeneous.

\section{Adsorption kinetics and mechanism of dye adsorption}

It is important to determine the kinetics of the $\mathrm{H} 6$ and $\mathrm{H} 8$ to understand their adsorption property. Four different kinetic models were used to fit the experimental data. They are pseudo-first, pseudo-second order, intra-particle diffusion and Elovich model.

The plots of adsorption of textile dyes RR and MB on H6 calcined at $300{ }^{\circ} \mathrm{C}$. The parameters of pseudo-first order, pseudo-second order, intra-particle diffusion and Elovich 
kinetic models are listed in Table S2 and Figs. S3 and S4 (c.f. Supplementary Data Section).

We can find that the $\left(q_{\mathrm{e}}^{\exp }\right)$ of the applied nanomaterials for different concentrations are more close to the $\left(\mathrm{q}_{\mathrm{e}}^{\mathrm{cal}}\right.$.) of pseudo-second order than pseudo-first-order kinetic model. In addition, the highest correlation coefficient $\left(R^{2}\right)$ values were obtained for pseudo-second-order kinetic model $\left(R^{2}=0.9821-1\right)$. Therefore, pseudo-second-order kinetic model is the best in describing the adsorption kinetics of $\mathrm{RR}$ or MB on different treated nanomaterials. Furthermore, we can observe that at low RR dye concentrations $(<50 \mathrm{ppm})$, the $k_{2}$ values are higher than the values at high concentrations stressing the increase of removal activity at low concentrations.

The experiment data were obtained by applying intraparticle diffusion model showing that the adsorption process displays multi-linear plot. The data gained of $k_{\mathrm{dif} 1}$ and $k_{\mathrm{dif} 2}$ (diffusion rate constants for phases I and II, respectively) from the slope of linear plots ranged between 1.7057-0.0568 and $1.037-0.041\left(\mathrm{mg} / \mathrm{min}^{1 / 2} \mathrm{~g}\right)$, respectively. The plot of two dyes did not pass through the origin. Therefore, the rate determining in the dyes adsorption process might be the boundary layer (film) diffusion.

The Elovich constants can be calculated from the slope and intercept of the line obtained by plotting $q_{t}$ vs. $\ln \mathrm{t}$ (c.f. Figs. S3 and S4).

These results inveterate that the adsorption process obeyed pseudo-second-order kinetic model signifying that two adsorption sites on modified adsorbent surface could be unavailable by one divalent dye ion probably as a result of the formation of $\left[\left(\mathrm{RR}^{-}\right)_{2}\right.$ and/or $\left.\mathrm{RR}(\mathrm{OH})_{2}^{-}\right]$or $\left[\left(\mathrm{MB}^{+}\right)_{2}\right.$ and/ or $\left.\mathrm{MBH}^{2+}\right]$ in aqueous solution. In addition, the rate-limiting step may be chemisorption, i.e., the electrostatic interactions between adsorbent positive charged and negatively charged dye molecule or vice versa.

We can predict the steps of adsorption process as the following: first, RR or MB transferred from the solution to the surface of $\mathrm{H} 6$ and $\mathrm{H} 8$. Then, the dye disperses from the exterior surface to interior pores of $\mathrm{H} 6$ or $\mathrm{H} 8$ through pore diffusion and finally, adsorption occurs in their active sites $\mathrm{CoFe}_{2} \mathrm{O}_{4}, \mathrm{C}$, and $\mathrm{Fe}_{2} \mathrm{O}_{3}$ on the surface. The spectra of RR and MB solutions in the range of 400-900 nm were done over $\mathrm{H} 6\left(300^{\circ} \mathrm{C}\right)$ and the results are shown in Fig. 10a, b. The maximum peaks of RR and MB were observed at $520 \mathrm{~nm}, 663 \mathrm{~nm}$, respectively. Figure 10a, b shows that the peaks at $520 \mathrm{~nm}$, and $663 \mathrm{~nm}$ decreased quickly and disappeared after 2-min and 30-min reaction time, implying the complete removal of RR and MB, respectively.

Furthermore, to clarify the mechanism involved in the dye removal process, two important points should be taken in consideration: first, the dye structure, and second, the surface properties of $\mathrm{H} 6$ or H8. Therefore, treatment of $\mathrm{CoFe}_{2} \mathrm{O}_{4}$ with HA led to the appearance of $\mathrm{C}$ phase as new
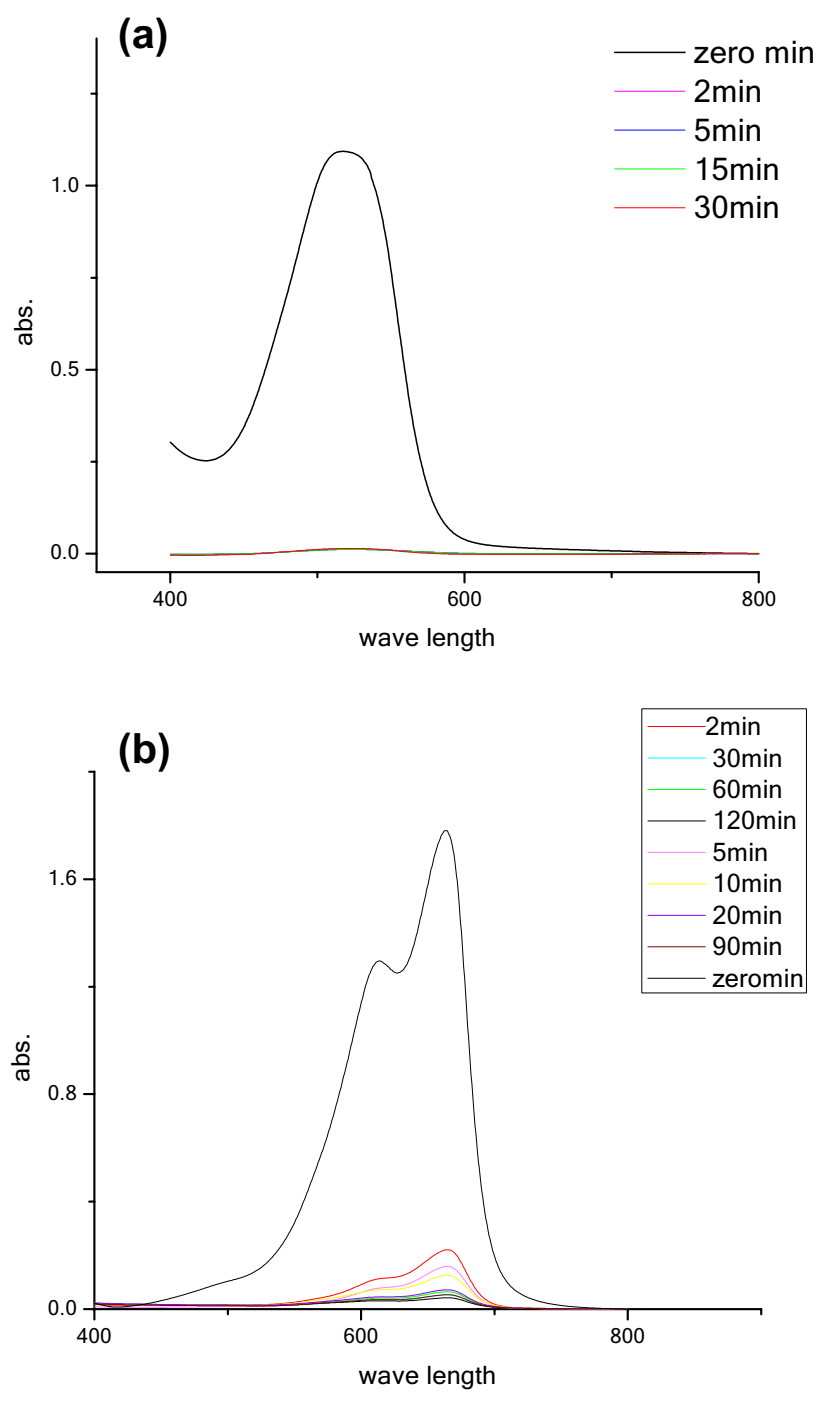

Fig. 10 a Adsorption spectra of $\mathrm{RR}$ dye onto $\mathrm{H6}\left(300^{\circ} \mathrm{C}\right)$ at $\mathrm{pH}=3$, conc. $=10 \mathrm{ppm}$, and $25^{\circ} \mathrm{C}$. $\mathbf{b}$ Adsorption spectra of MB dye onto $\mathrm{H} 6$ $\left(300{ }^{\circ} \mathrm{C}\right)$ at $\mathrm{PH}=11$, conc. $=10 \mathrm{ppm}$, and $25^{\circ} \mathrm{C}$

active sites for adsorption process beside the two phases $\left(\mathrm{CoFe}_{2} \mathrm{O}_{4}\right.$ and $\left.\mathrm{Fe}_{2} \mathrm{O}_{3}\right)$ and decreasing the crystallite size of $\mathrm{CoFe}_{2} \mathrm{O}_{4}$ component thereby enhances the surface area of the modified adsorbent (Tables 1,2). This likely increases the chemical interaction of MB or RR with treated solids as compared to unmodified adsorbents. In addition, the relation between the RR and MB structure and the surface charge of $\mathrm{H} 6$ and $\mathrm{H} 8$ solids will be taken in mind. Zeta-potential measurements in this study showed that the dye solution at a pH below the zero point charge $\left(\mathrm{pH}_{\mathrm{pzc}}\right)$ of adsorbent led to the surface of the sorbent positively charged and can attract anion dye (RR) from the solution (Table 2). So, an electrostatic attraction exists between positively charge surface of the adsorbent and the negatively charge of RR (which due to the presence of three $\mathrm{SO}_{3}$ groups on each molecule (c.f. Structure 1). Further poor adsorption has been observed in 


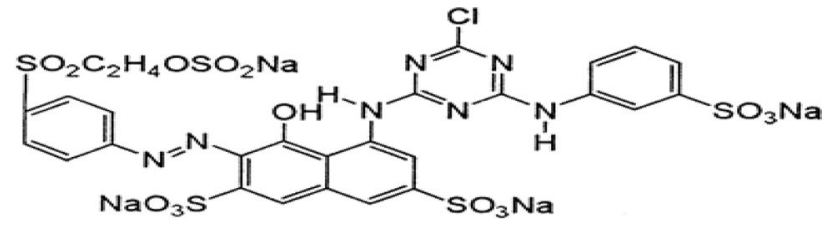

Structure 1 Molecular structure of the reactive dye, remazole-red (RR 133)

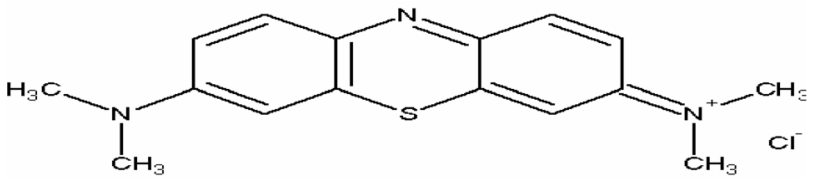

Structure 2 Molecular structure of the cationic dye, methylene blue (MB)

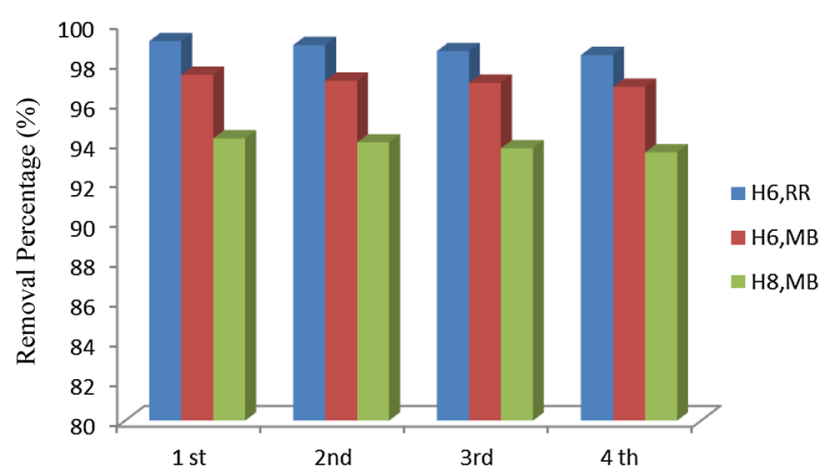

Fig. 11 Dye removal percentage by the used H6 and H8 $\left(300{ }^{\circ} \mathrm{C}\right)$ adsorbents recycled 4 times

the basic $\mathrm{pH}$ range $(\mathrm{pH}>\mathrm{pzc})$. It may be due to the deprotonation of functional groups giving rise to the electrostatic repulsion with RR. On the contrary, further the adsorption of MB occurs if the solution was at a $\mathrm{pH}$ higher than the zero point charge $\left(\mathrm{pH}_{\mathrm{pzc}}\right)$ of adsorbent which may be partly due to the electrostatic force operating between negatively charged groups present on the adsorbent surface and positive charge center of $\mathrm{MB}$ on the surface leading to the maximum adsorption of MB (c.f. Structure 2).

All of the previous reasons probably increase the concentrated bonding and the chemical interaction between MB or RR and treated adsorbents as compared to unmodified $\mathrm{CoFe}_{2} \mathrm{O}_{4}$ because of the easily penetrating of the dye molecule into the pores of $\mathrm{H} 6$ and $\mathrm{H} 8$ [65].

\section{Desorption and reuse results}

The RR desorption was possible with $\mathrm{NaOH}$, whereas, the $\mathrm{MB}$ was desorbed using $\mathrm{HCl}$. These returns confirm that the dye adsorption could be discussed through electrostatic interactions. Figure 11 shows the performance of $\mathrm{H} 6$ and $\mathrm{H} 8$ $\left(300{ }^{\circ} \mathrm{C}\right.$ ) adsorbents reusing for the removal of RR and MB from aqueous solution. The as-prepared adsorbents can be regenerated moderately and reused four times for both dyes, preserving nearly no change in removal efficiency.

Finally, we found that the novel adsorbents could be prepared with simple synthesis and modification method, quick adsorption kinetics through 2 min has been accomplished, and the largest adsorption capacity has got it for H6 and H8 novel adsorbents even if it is used for several times. Therefore, treated samples were shown to be as excellent adsorbents and can be considered as a promising material in wastewater treatment.

\section{Conclusion}

Unmodified $\mathrm{CoFe}_{2} \mathrm{O}_{4}$ solid and modified with HA were prepared via co-precipitation method. The ability of the asprepared solids to adsorb textile dye (RR and MB) from aqueous solution was investigated. Several factors impacted the adsorption capacity of these synthesized samples such as preparation condition, $\mathrm{pH}$, initial concentration of the dye solution, time of attack for both cationic and anionic dyes were studied. The obtained results showed that $\mathrm{H} 6$ and $\mathrm{H} 8$ materials achieved the goal, where the dye uptake reached $100 \%$ after a period of dye contact time not exceeding 2 min and 30 min for RR and MB dye, respectively. On the other hand, decreasing the $\mathrm{pH}$ of the $\mathrm{MB}$ dye solution led to decreasing the percent of dye removal. The vice versa was observed in the case of RR dye. Whereas, decreasing the concentration of dye solution led to increasing the adsorption capacity. Adsorption kinetic models as pseudo-first, pseudo-second order, intra-particle diffusion and Elovich model and adsorption isotherms models such as Langmuir, Freundlich, Temkin, and Dubinin-Radushkevich (D-R) models were applied in this study. The results indicated that the sorption routes were superior fitted by pseudo-secondorder equation and the Langmuir model. The mechanism of dye removal from its aqueous solution over $\mathrm{CoFe}_{2} \mathrm{O}_{4}$ modified with $\mathrm{HA}$ was proposed. In addition to that, $\mathrm{H} 6$ and $\mathrm{H} 8$ can be reused four times for dye removing, maintaining the same adsorption capacity. H6 adsorbent is more ideal and has greater potential for practical applications in the future.

\section{Compliance with ethical standards}

Conflict of interest The authors have declared that no competing interests found. 
Open Access This article is distributed under the terms of the Creative Commons Attribution 4.0 International License (http://creativeco mmons.org/licenses/by/4.0/), which permits unrestricted use, distribution, and reproduction in any medium, provided you give appropriate credit to the original author(s) and the source, provide a link to the Creative Commons license, and indicate if changes were made.

\section{References}

1. Mondal, S.: Methods of dye removal from dye house effluent-an overview. Environ. Eng. Sci. 25, 383-396 (2008)

2. Cardoso-Rurr, J.S., de Paiva, J.P., Paulino-Lima, I.G., de Alencar, T.A., Lage, C.A., Leitão, A.C.: Microbiological decontamination of water: improving the solar disinfection technique (SODIS) with the use of nontoxic vital dye methylene blue. Photochem. Photobiol. 95, 618-626 (2019)

3. O'Neil, M.J., Heckelman, P.E., Koch, C.B.: The Merck index-an encyclopedia of chemicals, drugs, and biologicals, version 14.6. Merck \& Co, New Jersey (2006)

4. National Toxicology Program. Toxicology and carcinogenesis studies of methylene blue trihydrate (Cas No. 7220-79-3) in F344/N rats and B6C3F1 mice (gavage studies). National Toxicology Program technical report series, (540), 1 (2008)

5. Eghbali, P., Hassani, A., Sündü, B., Metin, Ö.: Strontium titanate nanocubes assembled on mesoporous graphitic carbon nitride $\left(\mathrm{SrTiO}_{3} / \mathrm{mpg}-\mathrm{C}_{3} \mathrm{~N}_{4}\right)$ : preparation, characterization and catalytic performance. J. Mol. Liq. 290, 111208 (2019)

6. Hassani, A., Khataee, A., Karaca, S., Shirzad-Siboni, M.: Surfactant-modified montmorillonite as a nanosized adsorbent for removal of an insecticide: kinetic and isotherm studies. Environ. Technol. 36, 3125-3135 (2015)

7. Zhou, Y., Lu, J., Zhou, Y., Liu, Y.: Recent advances for dyes removal using novel adsorbents: a review. Environ. Pollut. 252 A, 352-365 (2019)

8. Aguiar, J.E., Cecilia, J.A., Tavares, P.A.S., Azevedo, D.C.S., Castellón, E.R., Lucena, S.M.P., SilvaJunior, I.J.: Adsorption study of reactive dyes onto porous clay heterostructures. Appl. Clay Sci. 135, 35-44 (2017)

9. He, W., Li, N., Wang, X., Hu, T., Bu, X.: A cationic metal-organic framework based on $\mathrm{Zn}_{4}$ cluster for rapid and selective adsorption of dyes. Chin. Chem. Lett. 29, 857-860 (2018)

10. Li, Y., Zhou, Y., Zhou, Y., Lei, J., Pu, S.: Cyclodextrin modified filter paper for removal of cationic dyes/Cu ions from aqueous solutions. Water Sci. Technol. 78, 2553-2563 (2018)

11. Attia, A.A., Rashwan, W.E., Khedr, S.A.: Capacity of activated carbon in the removal of acid dyes subsequent to its thermal treatment. Dyes Pigment. 69, 128-136 (2006)

12. Sharma, Y.C., Upadhyay, S.N.: An economically viable removal of methylene blue by adsorption on activated carbon prepared from rice husk. Can. J. Chem Eng. 89, 377-383 (2011)

13. Khataee, A.R., Fathinia, M., Aber, S., Zarei, M.: Optimization of photocatalytic treatment of dye solution on supported $\mathrm{TiO}_{2}$ nanoparticles by central composite design: intermediates identification. J. Hazard. Mater. 181, 886-897 (2010)

14. Hassani, A., Kiransan, M., Soltani, R.D.C., Khataee, A., Karaca, S.: Optimization of the adsorption of a textile dye onto nanoclay using a central composite design. Turk. J. Chem. 39, 734-749 (2015)

15. Uzun, I., Güzel, F.: Adsorption of some heavy metal ions from aqueous solution by activated carbon and comparison of percent adsorption results of activated carbon with those of some other adsorbents. Turk. J. Chem. 24, 291-298 (2000)
16. Qadeer, R., Rehan, A.H.: A study of the adsorption of phenol by activated carbon from aqueous solutions. Turk. J. Chem. 26, 357-362 (2002)

17. Gürses, A., Doğar, Ç., Karaca, S., Acikyildiz, M., Bayrak, R.: Production of granular activated carbon from waste Rosa canina sp. seeds and its adsorption characteristics for dye. J. Hazard. Mater. 131, 254-259 (2006)

18. Ambashta, R.D., Sillanpää, M.: Water purification using magnetic assistance: a review. J. Hazard. Mater. 180, 38-49 (2010)

19. Faraji, M., Yamini, Y., Rezaee, M.: Magnetic nanoparticles: synthesis, stabilization, functionalization, characterization, and applications. J. Iran. Chem. Soc. 7, 1-37 (2010)

20. Wang, N., Zhu, L., Wang, D., Wang, M., Lin, Z., Tang, H.: Sono-assisted preparation of highly-efficient peroxidase-like $\mathrm{Fe}_{3} \mathrm{O}_{4}$ magnetic nanoparticles for catalytic removal of organic pollutants with $\mathrm{H}_{2} \mathrm{O}_{2}$. Ultrason. Sonochem. 17, 526-533 (2010)

21. Petcharoen, K., Sirivat, A.: Synthesis and characterization of magnetite nanoparticles via the chemical co-precipitation method. Mater. Sci. Eng. B 177, 421-427 (2012)

22. Maity, D., Agrawal, D.C.: Synthesis of iron oxide nanoparticles under oxidizing environment and their stabilization in aqueous and non-aqueous media. J. Magn. Magn. Mater. 308, 46-55 (2007)

23. Mak, S.Y., Chen, D.H.: Fast adsorption of methylene blue on polyacrylic acid-bound iron oxide magnetic nanoparticles. Dyes. Pigment. 61, 93-98 (2004)

24. Chang, Y.C., Chang, S.W., Chen, D.H.: Magnetic chitosan nanoparticles: studies on chitosan binding and adsorption of Co (II) ions. React. Funct. Polym. 66, 335-341 (2006)

25. Ngomsik, A.F., Bee, A., Siaugue, J.M., Cabuil, V., Cote, G.: Nickel adsorption by magnetic alginate microcapsules containing an extractant. Water Res. 40, 1848-1856 (2006)

26. Liu, J.F., Zhao, Z.S., Jiang, G.B.: Coating $\mathrm{Fe}_{3} \mathrm{O}_{4}$ magnetic nanoparticles with humic acid for high efficient removal of heavy metals in water. Environ. Sci. Technol. 42, 6949-6954 (2008)

27. Tan, K.H.: Principles of soil chemistry. CRC Press, Boca Raton (2010)

28. Stevenson, F.J.: Humus chemistry, 2nd edn. Wiley, New York (1994)

29. Santosa, S.J., Tanaka, S., Siswanta, D., Kunarti, E.S., Sudiono, S., Rahmanto, W.H.: Indonesian peat soil derived humic acids, it's characterization, immobilization and performance as metal adsorbent. Proceeding of International Conference on Chemical Sciences (ICCS), Yogyakarta 2007

30. Illés, E., Tombácz, E.: The role of variable surface charge and surface complexation in the adsorption of humic acid on magnetite. Colloids Surf. A 230, 99-109 (2003)

31. Illés, E., Tombácz, E.: The effect of humic acid adsorption on $\mathrm{pH}$-dependent surface charging and aggregation of magnetite nanoparticles. J. Colloid. Interface. Sci. 295, 115-123 (2006)

32. Peng, L., Qin, P., Lei, M., Zeng, Q., Song, H., Yang, J., Gu, J.: Modifying $\mathrm{Fe}_{3} \mathrm{O}_{4}$ nanoparticles with humic acid for removal of Rhodamine B in water. J. Hazard. Mater. 209, 193-198 (2012)

33. Zhang, X., Zhang, P., Wu, Z., Zhang, L., Zeng, G., Zhou, C.: Adsorption of methylene blue onto humic acid-coated $\mathrm{Fe}_{3} \mathrm{O}_{4}$ nanoparticles. Colloids. Surf. A 435, 85-90 (2013)

34. Badawy A. A., Ibrahim S.M., Essawy H. A.: Enhancing the textile dye removal from aqueous solution using cobalt ferrite nanoparticles prepared by insertion of fulvic acid. J. Inorganic Organomet. Polym. Mater. (2019) (under press)

35. Fagal, G.A., Badawy, A.A., Hassan, N.A., El-Shobaky, G.A.: Effect of $\mathrm{La}_{2} \mathrm{O}_{3}$-treatment on textural and solid-solid interactions in ferric/cobaltic oxides system. J. Solid. State. Chem. 194, 162-167 (2012)

36. Cullity, B.D.: Publishing Cos, 2nd edn, p. 102. Addison-Wesley, Boston (1978) 
37. El-Shobaky, G.A., Yehia, N.S., Hassan, H.M., Badawy, A.A.: Catalytic oxidation of $\mathrm{CO}$ by $\mathrm{O}_{2}$ over nanosized $\mathrm{CuO}-\mathrm{ZnO}$ system prepared under various conditions. Can. J. Chem. Eng. 87, 792-800 (2009)

38. Rouquerol, J., Rouquerol, F., Llewellyn, P., Maurin, G., Sing, K. S. (2013). Adsorption by powders and porous solids: principles, methodology and applications. Academic press

39. Mahmoud, H.R., Ibrahim, S.M., El-Molla, S.A.: Textile dye removal from aqueous solutions using cheap $\mathrm{MgO}$ nanomaterials: adsorption kinetics, isotherm studies and thermodynamics. Adv. Powder Technol. 27, 223-231 (2016)

40. El-Harby, N.F., Ibrahim, S., Mohamed, N.A.: Adsorption of Congo red dye onto antimicrobial terephthaloyl thiourea cross-linked chitosan hydrogels. Water Sci. Technol. 76, 2719-2732 (2017)

41. Yang, X., Yi, H., Tang, X., Zhao, S., Yang, Z., Ma, Y., Feng, T., Cui, X.: Behaviors and kinetics of toluene adsorption-desorption on activated carbons with varying pore structure. J. Environ. Sci. 67, 104-114 (2018)

42. Ibrahim, M.M., El-Molla, S.A., Ismail, S.A.: Influence of $y$ and ultrasonic irradiations on the physicochemical properties of $\mathrm{CeO}_{2}-\mathrm{Fe}_{2} \mathrm{O}_{3}-\mathrm{Al}_{2} \mathrm{O}_{3}$ for textile dyes removal applications. J. Mol. Struct. 1158, 234-244 (2018)

43. Reddy, C.A., Saravanan, R.S.: Polymicrobial multi-functional approach for enhancement of crop productivity. Adv. Appl. Microbiol. 82, 53-113 (2013)

44. Ayawei, N., Ebelegi, A.N., Wankasi, D.: Modelling and interpretation of adsorption isotherms. J. Chem. 1, 1-11 (2017)

45. Khattri, S.D., Singh, M.K.: Colour removal from synthetic dye wastewater using a bioadsorbent. Water Air Soil Pollut. 120, 283-294 (2000)

46. Tsai, W.T., Hsu, H.C., Su, T.Y., Lin, K.Y., Lin, C.M.: Removal of basic dye (methylene blue) from wastewaters utilizing beer brewery waste. J. Hazard. Mater. 154, 73-78 (2008)

47. Ozdemir, F.A., Demirata, B., Apak, R.: Adsorptive removal of methylene blue from simulated dyeing wastewater with melamineformaldehyde-urea resin. J. Appl. Polym. Sci. 112, 3442-3448 (2009)

48. Kavitha, D., Namasivayam, C.: Experimental and kinetic studies on methylene blue adsorption by coir pith carbon. Biores. Technol. 98, 14-21 (2007)

49. Zhou, Y., Hu, Y., Huang, W., Cheng, G., Cui, C., Lu, J.: A novel amphoteric $\beta$-cyclodextrin-based adsorbent for simultaneous removal of cationic/anionic dyes and bisphenol A. Chem. Eng. J. 341, 47-57 (2018)

50. Tran, H.V., Bui, L.T., Dinh, T.T., Le, D.H., Huynh, C.D., Trinh, A.X.: Graphene oxide $/ \mathrm{Fe}_{3} \mathrm{O}_{4} /$ chitosan nanocomposite: a recoverable and recyclable adsorbent for organic dyes removal: Application to methylene blue. Mater. Res. Express 4, 035701 (2017)

51. Chen, D., Zeng, Z., Zeng, Y., Zhang, F., Wang, M.: Removal of methylene blue and mechanism on magnetic $\gamma-\mathrm{Fe}_{2} \mathrm{O}_{3} / \mathrm{SiO}_{2}$ nanocomposite from aqueous solution. Water Resour. Ind. 15, 1-13 (2016)

52. Essawy, A.A., Sayyah, S.M., El-Nggar, A.M.: Ultrasonicmediated synthesis and characterization of $\mathrm{TiO}_{2}$-loaded chitosan-grafted-polymethylaniline nanoparticles of potent efficiency in dye uptake and sunlight driven self-cleaning applications. RSC Adv. 6, 2279-2294 (2016)

53. Mahmoud, H.R., El-Molla, S.A., Saif, M.: Improvement of physicochemical properties of $\mathrm{Fe}_{2} \mathrm{O}_{3} / \mathrm{MgO}$ nanomaterials by hydrothermal treatment for dye removal from industrial wastewater. Powder Technol. 249, 225-233 (2013)

54. Ara, N.J., Hasan, M.A., Rahman, M.A., Salam, M.A., Salam, A., Alam, A.S.: Removal of remazol red from textile waste water using treated sawdust-an effective way of effluent treatment. Bangladesh Pharm. J. 16, 93-98 (2013)

55. Pala, A., Galiatsatou, P., Tokat, E., Erkaya, H., Israilides, C., Arapoglou, D.: The use of activated carbon from olive oil mill residue, for the removal of colour from textile wastewater. Eur. Water 13, 29-34 (2006)

56. Dizge, N., Aydiner, C., Demirbas, E., Kobya, M., Kara, S.: Adsorption of reactive dyes from aqueous solutions by fly ash: kinetic and equilibrium studies. J. Hazard. Mater. 150, 737-746 (2008)

57. Monteiro, M.S., de Farias, R.F., Chaves, J.A.P., Santana, S.A., Silva, H.A., Bezerra, C.W.: Wood (Bagassa guianensis Aubl) and green coconut mesocarp (Cocos nucifera) residues as textile dye removers (remazol red and remazol brilliant violet). J. Environ. Manag. 204, 23-30 (2017)

58. Khairy, M., Kamal, R., Amin, N.H., Mousa, M.A.: Kinetics and isotherm studies of remazol red adsorption onto polyaniline/cerium oxide nanocomposites. J. Basic Environ. Sci. 3, 123-132 (2016)

59. Travis, C.C., Etnier, E.L.: A survey of sorption relationships for reactive solutes in soil. J. Environ. Qual. 10, 8-17 (1981)

60. Celebi, O., Üzüm, Ç., Shahwan, T., Erten, H.N.: A radiotracer study of the adsorption behavior of aqueous $\mathrm{Ba}^{2+}$ ions on nanoparticles of zero-valent iron. J. Hazard. Mater. 148, 761-767 (2007)

61. Ayawei, N., Ekubo, A.T., Wankasi, D., Dikio, E.D.: Adsorption of congo red by Ni/Al- $-\mathrm{CO}_{3}$ : equilibrium, thermodynamic and kinetic studies. Orient. J. Chem. 31, 1307 (2015)

62. Ayawei, N., Ekubo, A.T., Wankasi, D., Dikio, E.D.: Adsorption of congo red by $\mathrm{Ni} / \mathrm{Al}-\mathrm{CO}_{3}$ : equilibrium, thermodynamic and kinetic studies. Orient. J. Chem. 31, 1307 (2015)

63. Shahbeig, H., Bagheri, N., Ghorbanian, S.A., Hallajisani, A., Poorkarimi, S.: A new adsorption isotherm model of aqueous solutions on granular activated carbon. World J. Model. Simul. 9, 243-254 (2013)

64. Vijayaraghavan, K., Padmesh, T.V.N., Palanivelu, K., Velan, M.: Biosorption of nickel (II) ions onto Sargassum wightii: application of two-parameter and three-parameter isotherm models. J. Hazard. Mater. 133, 304-308 (2006)

65. Mashkoor, F., Nasar, A.: Preparation, characterization and adsorption studies of the chemically modified Luffa aegyptica peel as a potential adsorbent for the removal of malachite green from aqueous solution. J. Mol. Liq. 274, 315-327 (2019)

Publisher's Note Springer Nature remains neutral with regard to jurisdictional claims in published maps and institutional affiliations.

\section{Affiliations}

\section{Shaimaa M. Ibrahim ${ }^{1} \cdot$ Abdelrahman A. Badawy $^{2}$ (I) $\cdot$ Hisham A. Essawy ${ }^{3}$}

1 Chemistry Department, Faculty of Education, Ain Shams University, Cairo, Egypt

2 Physical Chemistry Department, National Research Centre, Dokki, Cairo 12622, Egypt
3 Department of Polymers and Pigments, National Research Centre, Dokki, Cairo 12622, Egypt 